\title{
Cdc25A Is a Critical Mediator of Ischemic Neuronal Death In Vitro and In Vivo
}

\author{
[Q Grace 0. Iyirhiaro, ${ }^{1}$ Doo Soon Im, ${ }^{1}$ Wassamon Boonying, ${ }^{1}$ SSteve M. Callaghan, ${ }^{1}$ Matthew J. During, ${ }^{2}$ Ruth S. Slack, ${ }^{1}$ \\ and ${ }^{-D a v i d}$ S. Park ${ }^{1}$ \\ ${ }^{1}$ University of Ottawa Brain and Mind Research Institute, Department of Cellular and Molecular Medicine, University of Ottawa, Ottawa, Ontario K1H 8M5, \\ Canada, and 2 Department of Molecular Virology, Immunology and Medical Genetics, and Neurological Surgery, College of Medicine, The Ohio State \\ University, Columbus, Ohio 43210
}

Dysregulation of cell cycle machinery is implicated in a number of neuronal death contexts, including stroke. Increasing evidence suggests that cyclin-dependent kinases (Cdks) are inappropriately activated in mature neurons under ischemic stress conditions. We previously demonstrated a functional role for the cyclin D1/Cdk4/pRb (retinoblastoma tumor suppressor protein) pathway in delayed neuronal death induced by ischemia. However, the molecular signals leading to cyclin D/Cdk4/pRb activation following ischemic insult are presently not clear. Here, we investigate the cell division cycle 25 (Cdc25) dual-specificity phosphatases as potential upstream regulators of ischemic neuronal death and Cdk4 activation. We show that a pharmacologic inhibitor of Cdc 25 family members $(\mathrm{A}, \mathrm{B}$, and C) protects mouse primary neurons from hypoxia-induced delayed death. The major contributor to the death process appears to be Cdc25A. shRNA-mediated knockdown of Cdc25A protects neurons in a delayed model of hypoxia-induced death in vitro. Similar results were observed in vivo following global ischemia in the rat. In contrast, neurons singly or doubly deficient for $\mathrm{Cdc} 25 \mathrm{~B} / \mathrm{C}$ were not significantly protective. We show that Cdc25A activity, but not level, is upregulated in vitro following hypoxia and global ischemic insult in vivo. Finally, we show that shRNA targeting Cdc25A blocks Ser795 pRb phosphorylation. Overall, our results indicate a role for Cdc25A in delayed neuronal death mediated by ischemia.

Key words: Cdc25; cell cycle; hypoxia; ischemia; neuronal death; stroke

\section{Significance Statement}

A major challenge in stroke is finding an effective neuroprotective strategy to treat cerebral ischemic injury. Cdc25 family member $\mathrm{A}(\mathrm{Cdc} 25 \mathrm{~A})$ is a phosphatase normally activated during cell division in proliferating cells. We found that Cdc25A is activated in neurons undergoing ischemic stress mediated by hypoxia in vitro and global cerebral ischemia in rats in vivo. We show that pharmacologic or genetic inhibition of $\mathrm{Cdc} 25 \mathrm{~A}$ activity protects neurons from delayed death in vitro and in vivo. Downregulation of $\mathrm{Cdc} 25 \mathrm{~A}$ led to reduction in retinoblastoma tumor suppressor protein ( $\mathrm{pRb}$ ) phosphorylation. An increase in pRb phosphorylation has been previously linked to ischemic neuronal death. Our results identify Cdc $25 \mathrm{~A}$ as a potential target for neuroprotectant strategy for the treatment of delayed ischemic neuronal death.

\section{Introduction}

The regulation of ischemic neuronal death involves a network of death signals. One such pathogenic signal involves the activation

Received Sept. 27, 2016; revised May 26, 2017; accepted May 30, 2017.

Author contributions: G.0.I., R.S.S., and D.S.P. designed research; G.0.I., D.S.I., W.B., S.M.C., and M.J.D. performed research; G.0.I. analyzed data; G.O.I. wrote the paper.

This work was supported by grants from the Heart and Stroke Foundation of Canada, the Heart and Stroke Foundation of Ontario (HSFO), the Canadian Institutes of Health Research, and the Krembil Foundation/Brain Canada (to D.S.P.). D.S.P. is an HSFO scholar. We thank Dr. Helen Piwnica-Worms, Washington University School of Medicine in St. Louis, for generously providing us with Cdc25B/C transgenic mice. We also thank Carmen Estey for technical assistance.

The authors declare no competing financial interests.

Correspondence should be addressed to Dr. David S. Park, Department of Cellular and Molecular Medicine, Neuroscience, University of 0ttawa, 451 Smyth Road, 0ttawa, 0N K1H 8M5, Canada. E-mail: dpark@uottawa.ca. of cyclin-dependent kinases (Cdks). These are a family of proline directed serine/threonine kinases that play important roles in a number of biological processes, including cell division, transcription, neuronal development, and death (Pines, 1995; Dhavan and Tsai, 2001; Gopinathan et al., 2011; Herrup, 2012). With respect to the latter, the involvement of Cdks has been reported in a number of pathologic stress models, including DNA damage (Park et al., 1997, 1998a,b, 2000), oxidative stress (Zambrano et al., 2004), excitotoxicity (O'Hare et al., 2005), and amyloid- $\beta$ toxicity (Giovanni et al., 2000; Liu et al., 2004). Importantly, 
Cdks are also implicated in a number of neurodegenerative conditions, including Parkinson's disease (Jordan-Sciutto et al., 2003; Smith et al., 2003), Alzheimer's disease (Hernández-Ortega et al., 2011; Moh et al., 2011), amyotrophic lateral sclerosis (Nguyen and Julien, 2003), and stroke (Osuga et al., 2000; Rashidian et al., 2007). Of relevance to the present study is the evidence demonstrating the involvement of core cell cycle proteins, in particular cyclin $\mathrm{D} / \mathrm{Cdk} 4$, in ischemic neuronal death (Guégan et al., 1997; Katchanov et al., 2001; Rashidian et al., 2005).

Cdk4 regulates the G1/S-phase transition in proliferating cells. During the G1/S-phase Cdk4 associates with cyclin D and is activated via phosphorylation by cyclin-dependent kinase activating kinase (Pines, 1995). It has been proposed that Cdk4 is also positively regulated by a mandatory dephosphorylation of an inhibitory tyrosine within the ATP binding site by members of the cell division cycle 25 (Cdc25) dual-specificity phosphatases (Pines, 1995). Once activated, Cdk4 phosphorylates the retinoblastoma tumor suppressor protein ( $\mathrm{pRb}$ ), leading to its inactivation and the release of the E2F transcription factors (Pines, 1995). Together with its coactivator Dp1, E2F1 mediates the transcription of genes required for the progression to the $S$ phase (Pines, 1995).

In neurons, empirical evidence supports the role of $\mathrm{Cdk} 4$ as a death mediator under ischemic stress. First, cyclin D1 and Cdk4 levels and activity are increased in models of cerebral ischemia, including oxygen glucose deprivation (Katchanov et al., 2001), focal ischemia (Katchanov et al., 2001; Wen et al., 2005; Cai et al., 2009), and global ischemia (Timsit et al., 1999; Small et al., 2001). In addition, an increase in cyclin D1 immunoreactivity is observed in human stroke brains (Love, 2003). Second, pharmacologic inhibition of Cdks is protective in focal (Osuga et al., 2000) and global (Wang et al., 2002) ischemic models. Importantly, the expression of kinase dead Cdk4 is protective against delayed neuronal death induced by hypoxia and global ischemia (Rashidian et al., 2005).

Critical downstream targets of Cdk4 have also been implicated in neuronal death. For example, we have shown that the $\mathrm{pRb}$ is increasingly phosphorylated following hypoxia/reoxygenation and global ischemic insults (Rashidian et al., 2005). This ischemia-induced pRb phosphorylation is attenuated by dominant-negative Cdk4 expression (Rashidian et al., 2005). Similarly, E2F1 levels are induced in models of cerebral ischemia (Osuga et al., 2000; Gendron et al., 2001; Hwang et al., 2006), and its deficiency has been shown to be protective (MacManus et al., 1999, 2003; Gendron et al., 2001). While these studies have helped to elucidate the downstream effectors of Cdk4, very little is known of the upstream signals leading to its activation following ischemic stress. Here we provide evidence for a central role of Cdc25A in delayed ischemic death both in vitro and in vivo.

\section{Materials and Methods}

Viral construction. Recombinant adeno-associated virus (rAAV) vectors expressing EGFP and shRNA to Cdc25 family member A (Cdc25A) were constructed by subcloning the $\mathrm{p}$-Silencer $\mathrm{H} 1$ expression cassette (catalog \#AM7120, Ambion) into the KpnI sites of a modified AM/chicken $\beta$-actin (CBA)-EGFP-pl-WPRE-bGH plasmid. Briefly, the AM/CBAEGFP-pl-WPRE-bGH plasmid was digested with BamHI and HindIII and then blunted by removing the multiple cloning sites (MCSs) region. The EGFP fragment from pEGFP-N2 (catalog \#6081-1, Clontech) replaced the MCS to produce AM/CBA-EGFP-pl-WPRE-bGH. The reengineered AM/CBA-EGFP-pl-WPRE-bGH vector was redigested with KpnI and blunted. The pSilencer 3.0 HI vector (catalog \#AM7210, Ambion) was digested with PVUII, and the expression cassette containing the $\mathrm{H} 1$ promoter, and BamHI and HindIII sites was subcloned into the blunted
AM/CBA-EGFP-pl-WPRE-bGH vector. shRNA targeting Cdc25A; shRNA 1, 5'-GCCGATACCCATATGAATA-3' (catalog\#S139728, Ambion); shRNA 2, 5'-GAAATATATTTCTCCAGAA-3' (catalog \#S139729, Ambion); Cdc25B 5' AGAGAGTGATTTAAAGGAT-3' (catalog \#S139731, Ambion); and Cdc25C 5'-CCATTACTACAGTTCCAAA-3' (catalog \#S158198, Ambion) or pSilencer control (ctrl) 1 shRNA 5'-AGTACTGCTTACGATACGG-3' (Ambion) were subcloned into BamHI and HindIII sites within the HI expression cassette in the new AAV vector (AM/CBA-EGFP-HI-pl-WPRE-bGH). The final rAAV vector contained two separate promoters, CBA and HI, that drove the expression of GFP and shRNA, respectively. The vectors containing control shRNA or Cdc25A shRNA were used to produce rAAVs, as previously described (Zolotukhin et al., 2002). Viral efficiency was tracked using GFP expression.

Cdc25B- and Cdc25C-null mice. Cdc25B and Cdc25C double-null mice on C57BL/6; 129X1SvJ background have been previously described (Ferguson et al., 2005). The mice were obtained from Dr. Helen Piwnica-Worms (Department of Cell Biology and Physiology, Washington University School of Medicine in St. Louis, St. Louis, MO). Male mice null for Cdc25B and Cdc25C were bred to wild-type C57BL/6 female mice (Charles River) to generate double-heterozygous mice. Mice heterozygous for Cdc25B or $\mathrm{Cdc} 25 \mathrm{C}$ were derived from subsequent brother-sister mating. Mice singly or doubly heterozygous for $\mathrm{Cdc} 25 \mathrm{~B}$ and/or Cdc25C were bred and genotyped by PCR using primers $5^{\prime}$-GACTGTAGGGACAGGGTCCA-3', 5' -GCAGCCTGCTACAAAGTTCC-3', 5'-TAGTGACCACCGTGGACTGA-3', and 5'-GGGAGGATTGGGAAGACAAT-3' for Cdc25B and 5' -GGTTCCTTGGATTCATCTGGAC-3' 5' $^{\prime}$-CCCTACCATGAGTGCAGGGCACC-3' ${ }^{\prime}$, and 5'-CCTCGTGCTTTACGGTATCGCC-3' for Cdc25C.

Cell culture and treatments. Primary cerebellar granule neuron (CGN) cultures were harvested from 7 to $9 \mathrm{~d}$ postnatally from CD1 Wistar rats (Charles River) or from Cdc25B and/or Cdc25C single- or double knockout mice (on C57BL/6 on 129X1SvJ background) as previously described (O'Hare et al., 2000). CGN cultures were treated with Cdc25 inhibitor NSC95397 [2,3-bis-(2-hydroxyethylsulfanyl)-1,4-naphtho-quinone], which was provided by the Drug Synthesis and Chemistry Branch, National Cancer Institute (Bethesda, MD). A 10 mm stock solution of NSC95397 prepared in dimethylsulfoxide (DMSO) and stored at $-80^{\circ} \mathrm{C}$ was diluted in complete CGN media immediately before use. Alternatively, CGNs were infected with rAAV-expressing shRNA to Cdc25A or control 1 shRNA as control at 50 or 200 IFU (infectious units). All CGN cultures were subjected to hypoxia or glutamate insult after 1 week in culture.

Hypoxia. Hypoxia was conducted as previously described (Rashidian et al., 2005) using a humidified environmental hypoxia chamber (Coy Laboratory Products) set at $37^{\circ} \mathrm{C}, 1 \% \mathrm{O}_{2}$, and $5 \% \mathrm{CO}_{2}$, and balanced with $\mathrm{N}_{2}$. Gas levels were electronically monitored and maintained at set values. Delayed and excitotoxic hypoxic death models were performed as previously described (Rashidian et al., 2005). Briefly, delayed hypoxic death was induced by incubating CGN cultures in the hypoxia chamber for $18 \mathrm{~h}$ in the presence of the $10 \mu \mathrm{M}$ NMDA blocker MK801 (catalog $\# \mathrm{M}-108$, Research Biochemicals) and then reoxygenated at $37^{\circ} \mathrm{C}$. Control cultures were incubated at $37^{\circ} \mathrm{C}$ and were not subjected to hypoxia (Rashidian et al., 2005). Alternatively, excitotoxic hypoxic death was induced by incubating CGN cultures in the hypoxia chamber in the absence of MK801 for $5 \mathrm{~h}$ and reoxygenated for $1 \mathrm{~h}$ at $37^{\circ} \mathrm{C}$. Non-virally infected cultures were lysed at various times after hypoxia using mildly disruptive lysis buffer, as previously described (Rashidian et al., 2005). Nuclei of healthy cells remained intact and were counted. The nuclei of unhealthy cells showed a disrupted nuclear membrane and characteristics of blebbing and were excluded.

Virally infected cells were fixed 1:1 with $4 \%$ paraformaldehyde and Lana's fixative and stained with Hoechst 33258 stain (catalog \#B1155, Sigma-Aldrich). Neuronal survival was evaluated by examining the nuclear integrity of GFP-positive cells in random fields as previously described (O'Hare et al., 2005). Dying neurons exhibited severe nuclear condensation or fragmentation. For delayed death, live neurons were scored over total GFP-positive cells. For excitotoxic death, total live GFPs from five random fields were counted and presented as the percentage of survival \pm SEM

Glutamate exposure. CGNs were transiently exposed to $50 \mu \mathrm{M}$ glutamate for $70 \mathrm{~min}$ in the presence or absence of MK801 after 1 week in 


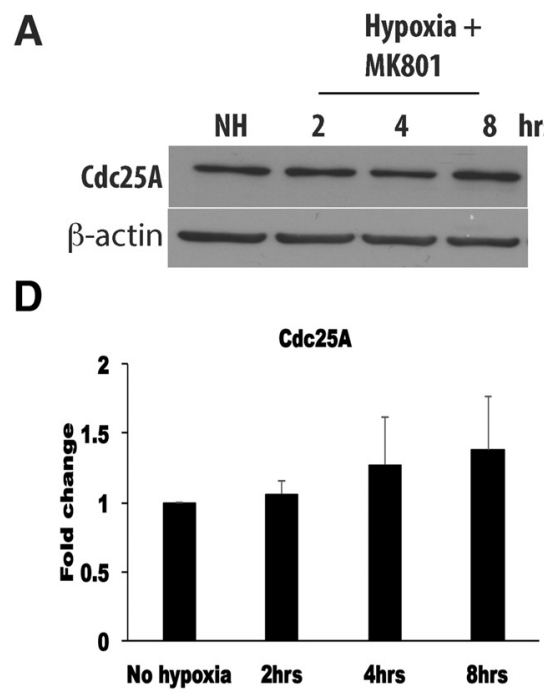

G

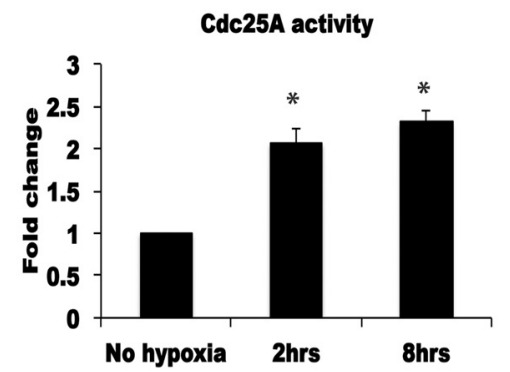

B

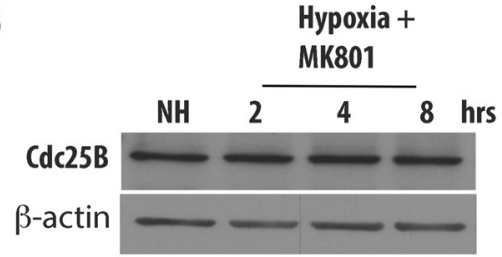

E

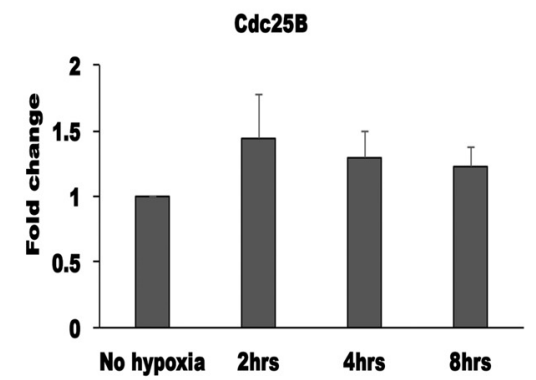

H

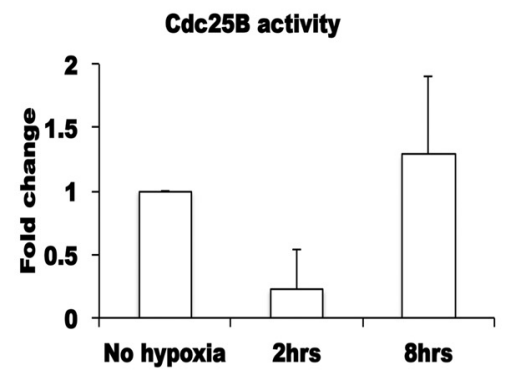

C

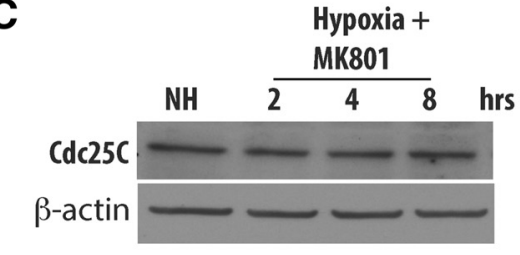

F

Cdc25C

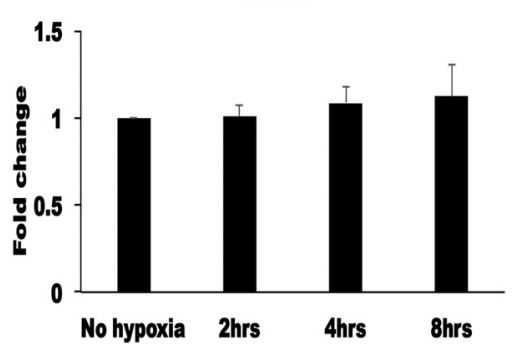

I

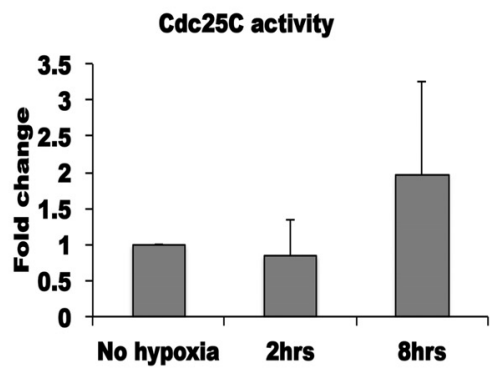

Figure 1. Cdc25A activity is increased following hypoxic insult in vitro. A-C, CGN cultures were subjected to hypoxia in the presence of MK801. At the indicated times, the cells were harvested and subjected to Western blot analysis and probed with anti-Cdc25A ( $N=8$ independent experiments; $\boldsymbol{A})$, anti-Cdc25B $(N=5$ independent experiments; $\boldsymbol{B})$, and anti-Cdc25C $(N=5$ independent experiments; $\boldsymbol{C}$ ) antibodies. $\boldsymbol{D}-\boldsymbol{F}$, densitometry of changes in $\mathrm{Cdc} 25 \mathrm{~A}(\boldsymbol{D}), \mathrm{Cdc25B}(\boldsymbol{E})$, and $\operatorname{Cdc} 25 \mathrm{C}(\boldsymbol{F})$ protein levels relative to no hypoxia (NH) control. $\mathbf{G}-\boldsymbol{I}$, phosphatase activity of $\mathrm{Cdc} 25 \mathrm{~A}(\mathrm{~N}=$ 4 independent experiments; $\boldsymbol{G}),(\mathrm{Cd} 25 \mathrm{~B}(\boldsymbol{N}=4$ independent experiments; $\boldsymbol{H})$, and $\operatorname{Cdc} 25 \mathrm{C}(\boldsymbol{N}=3$ independent experiments; $\boldsymbol{I})$ were conducted following hypoxia in the presence of MK801. Following hypoxia, (dc25 was immunoprecipitated and subjected to phosphatase assay using pNPP as a substrate. Cdc25 activity was assayed by measuring the liberation of pNPP substrate at $0 D$ 410. Results are expressed as the fold change over the no-hypoxia control \pm SEM. ${ }^{*} p<0.05$, statistical significance compared with no hypoxia control (one-way ANOVA, followed by Dunn's multiple-comparison test).

culture and were treated as previously described (Rashidian et al., 2005). In brief, cultures were washed with conditioned media after 70 min and incubated for $1 \mathrm{~h}$ at $37^{\circ} \mathrm{C}$. Neuronal survival was examined and scored as described above.

Viral injections in vivo. All animal experiments were performed in accordance with the guidelines set forth by the Canadian Council for the Use and Care of Animals in Research with approval from the University of Ottawa Animal Care Committee. Male Wistar rats weighing 80-125 g were unilaterally injected with rAAV-expressing shRNA targeting Cdc25A or control shRNA and GFP 2 weeks before global cerebral ischemia, as previously described (Rashidian et al., 2005) with the following modification: $2 \mu \mathrm{l}$ of $\mathrm{rAAV}\left(10^{11} \mathrm{IFU} / \mu \mathrm{l}\right)$ with $1 \mu \mathrm{l}$ of $20 \%$ mannitol in PBS was stereotaxically delivered over $30 \mathrm{~min}$ to the hippocampus (from bregma: $-3.6 \mathrm{~mm}$ anteroposterior, $\pm 2.1 \mathrm{~mm}$ lateral, and $-2.75 \mathrm{~mm}$ deep) using an infusion pump (Harvard Apparatus).

Global cerebral ischemia. rAAV-injected and noninjected male Wistar rats were subjected to the four-vessel occlusion (4VO) method of transient global cerebral ischemia for $10 \mathrm{~min}$ as previously described (Wang et al., 2002; Iyirhiaro et al., 2008). Rats were killed 4 d following global ischemia and assessed for CA1 neuron survival. Brains were extracted, sectioned, and stained with hematoxylin and eosin. Neuronal survival was evaluated as previously described (Wang et al., 2002; Iyirhiaro et al., 2008).

Immunohistochemistry. Deparaffinization and heat-mediated antigen retrieval using citrate buffer $(50 \mathrm{~mm}[\mathrm{SCAP}]), \mathrm{pH} 7.6$, was performed on rat brain sections as previously described (Iyirhiaro et al., 2008). Sections were permeabilized for 10 min with $0.3 \%$ Triton X-100 and blocked in
$10 \%$ normal goat serum (catalog \#005-000-121, Jackson ImmunoResearch; RRID:AB_2336990) diluted in 2\% bovine serum albumin (Fisher Scientific) in $0.01 \mathrm{~m}$ PBS for $1 \mathrm{~h}$ at room temperature. This was followed by an overnight incubation at $4^{\circ} \mathrm{C}$ with mouse monoclonal anti-GFP antibody (catalog \#ab1218, Abcam; RRID:AB_298911; 1:200). The sections were subsequently incubated with Alexa Fluor 488 goat anti-mouse secondary antibody (1:200; catalog \#A-11001, Thermo Fisher Scientific; RRID:AB_2534069) for $1 \mathrm{~h}$ at room temperature and stained with Hoechst stain.

Phosphatase assay. Cdc25A, Cdc25B, and Cdc25C phosphatase activity was assayed by monitoring the hydrolysis of 4-nitrophenol phosphate (pNPP; catalog \#N4645, Sigma-Aldrich) as previously described (Zhang et al., 2006). Hippocampal tissues were extracted at designated times following $4 \mathrm{VO}$ and homogenized in immunoprecipitation buffer $(50 \mathrm{~mm}$ HEPES, pH 7.5, 150 mм NaCl, 1 mм EDTA, 2.5 mм EGTA, 1 mм DTT, $0.1 \%$ Tween 20 , and protease inhibitor cocktail; catalog \#04693159001, Roche). A total of $100-200 \mu \mathrm{g}$ of total protein from CGN or hippocampal lysate was incubated with $2 \mu \mathrm{g}$ of rabbit polyclonal anti-Cdc25A (catalog \#sc-97, Santa Cruz Biotechnology; RRID:AB_2075041), anti-Cdc25B (catalog \#sc-5619, Santa Cruz Biotechnology; RRID:AB_2275778), or antiCdc25C (catalog \#sc-327, Santa Cruz Biotechnology; RRID:AB_2075277) antibody overnight at $4^{\circ} \mathrm{C}$. As control, anti-HA (catalog \#sc-805, Santa Cruz Biotechnology; RRID:AB_631618) or anti-Igg (catalog \#sc-2027, Santa Cruz Biotechnology; RRID:AB_737197) was added to control lysates. The antigen-antibody complex was captured with protein A-Sepharose beads (cata$\log$ \#P3391, Sigma-Aldrich) for $4 \mathrm{~h}$ at $4^{\circ} \mathrm{C}$. The bead-antigen-antibody complex was subsequently incubated with phosphatase reaction buffer con- 
A
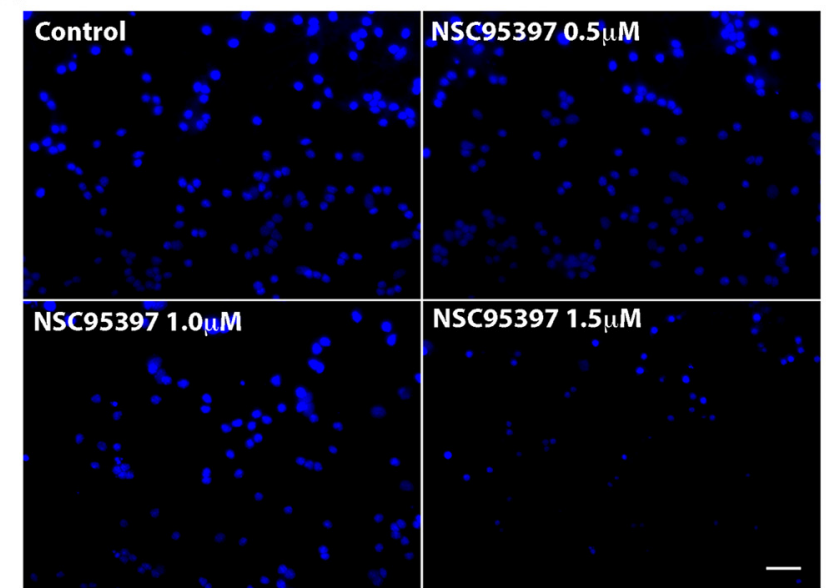

B

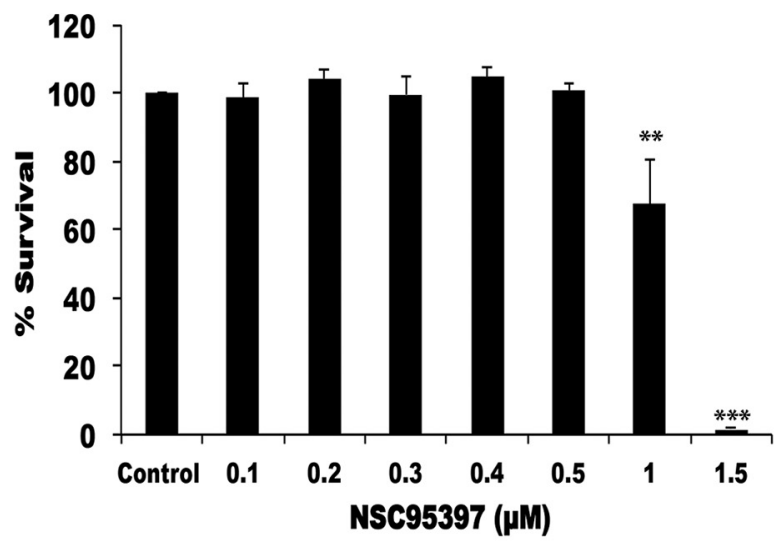

C

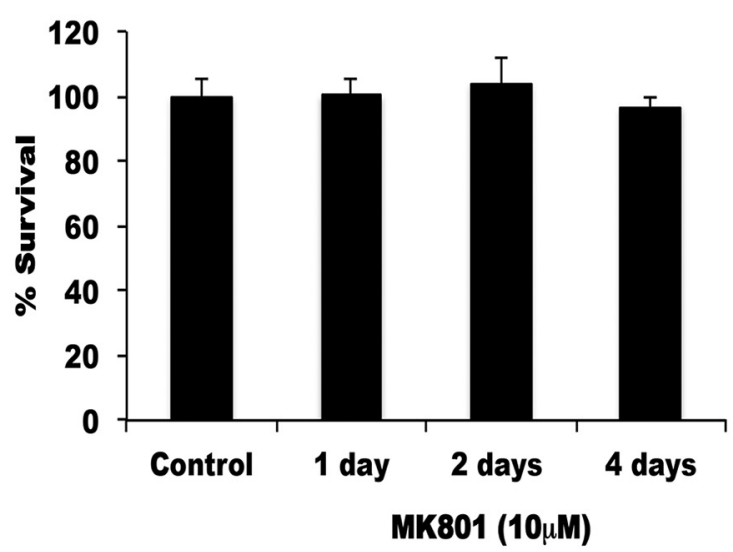

D

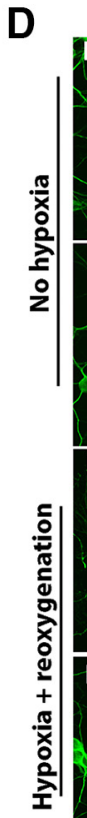

$\mathbf{E}$

MAP2

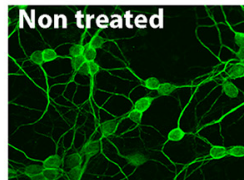

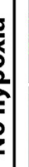

NSC95397

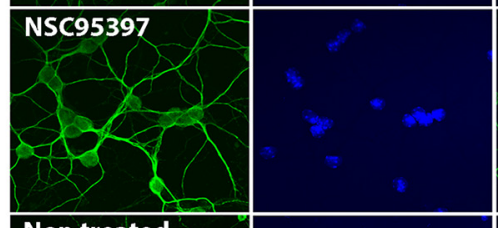

Hoechst
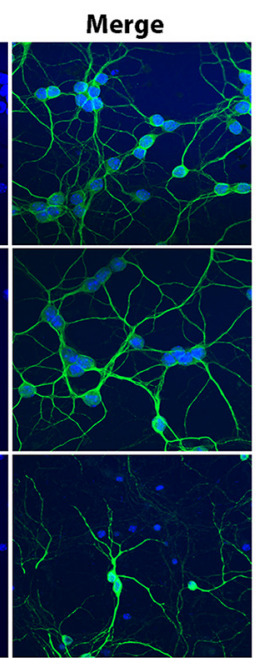

NSC95397
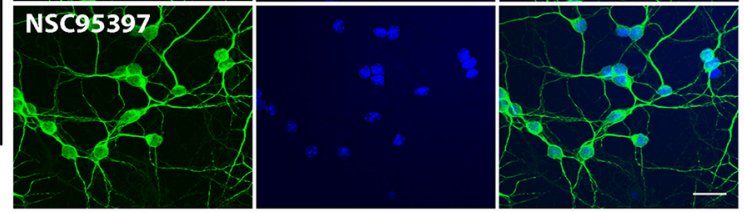

$\square$ No Hypoxia $\square$ No Hypoxia + MK801 $\square 1$ day $\square 2$ days $\square 4$ days

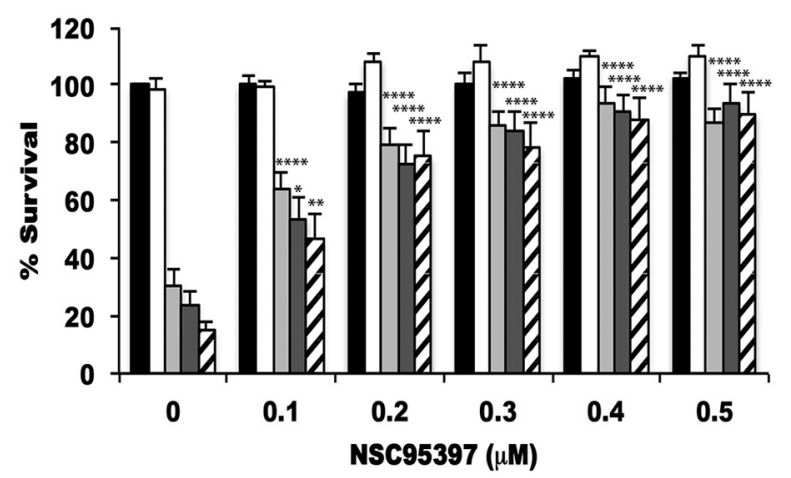

Figure 2. Treatment with the Cdc25 phosphatase inhibitor (NSC95397) protects neurons from delayed cell death induced by hypoxia. $A, B$, Cytotoxicity of NSC95397 was evaluated in CGN cultures. $A, B$, Neurons were treated with different concentrations of NSC95397, and fixed and stained with Hoechst stain $(\boldsymbol{A})$, and the quantitation of neuronal survival $24 \mathrm{~h}$ following NSC95397 treatment of $\mathrm{CGN}$ cultures was performed $(\boldsymbol{B}) . N=3$ independent experiments. ${ }^{* *} p<0.01,{ }^{* * *} p<0.005$, statistical significance compared with no drug control. $C$, CGNs were treated with $10 \mu \mathrm{m}$ MK801 for up to $4 \mathrm{~d}$ and assessed for neuronal survival. $N=4 . D, E$, CGNs treated with varying concentrations of NSC95397 were subjected to $18 \mathrm{~h}$ of hypoxia in the presence of MK801 followed by reoxygenation for 1, 2, and 4 d. D. Confocal microscopy images showing nontreated and NSC95397-treated neuronal cultures taken $24 \mathrm{~h}$ after hypoxia. Control cultures did not undergo hypoxia treatment. Neurons were stained with the neuronal marker MAP-2 (green) and Hoechst stain (blue). Scale bar, $30 \mu \mathrm{m}$. $E$, Neurons were treated with no drug or with varying concentrations of the Cdc25 inhibitor NSC95397 and were subjected to hypoxia plus MK801. Neuronal survival was quantitated 1,2, and $4 \mathrm{~d}$ after hypoxia. Results are expressed as the percentage of control \pm SEM. ${ }^{*} p<0.05,{ }^{* *} p<0.01,{ }^{* * * *} p<0.0001$, statistical significance compared with hypoxia-treated neurons, with no drug control (two-way ANOVA, followed by Bonferroni's test). $N \geq 3$.

taining 50 mm Tris, pH 8.0, 50 mm NaCl, 1 mm EDTA, 1 mm DTT, and 1 mm pNPP overnight at $37^{\circ} \mathrm{C}$. The reaction was stopped by the addition of $5 \mathrm{~N}$ $\mathrm{NaOH}$. Cdc25A phosphatase activity was monitored by measuring the absorbance of $p$-nitrophenol at $410 \mathrm{~nm}$.

Western blot analysis. At the designated times following hypoxia or glutamate treatment in vitro, whole-cell lysate was collected and sub- jected to Western blot analysis. Whole hippocampal or nuclear extract was collected from rats treated with global ischemia and reperfusion at the indicated times or injected with AAV-expressing shRNA to Cdc25A. Nuclear proteins were extracted from hippocampal brain lysates as previously described (Wang et al., 2002). Samples were run on SDS-polyacrylamide gels and transferred onto PVDF membrane (catalog \#IPVH00010, Millipore). 
A

GFP

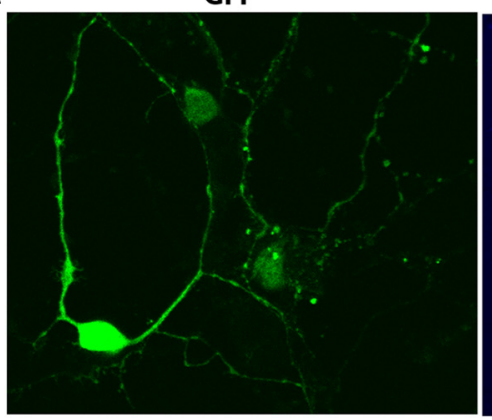

B

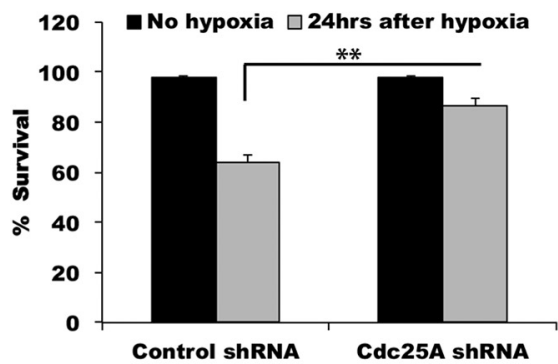

D

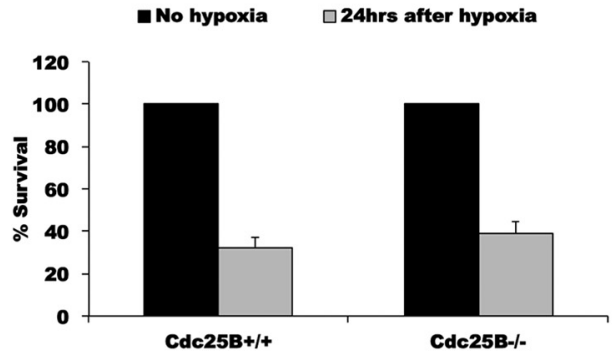

$\mathbf{F}$

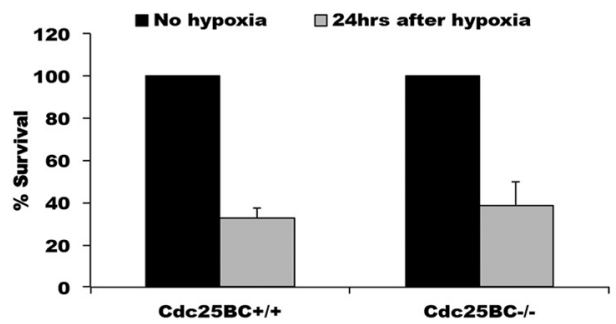

H

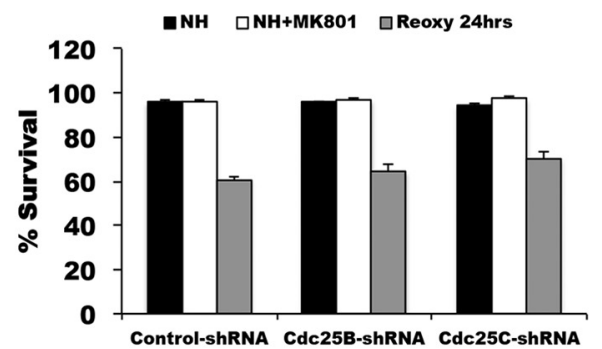

Hoechst

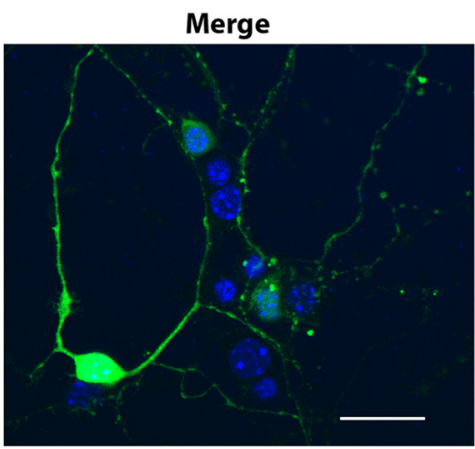

C

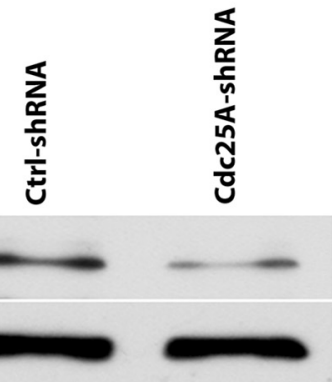

E

Eo hypoxia $\square$ 24hrs after hypoxia

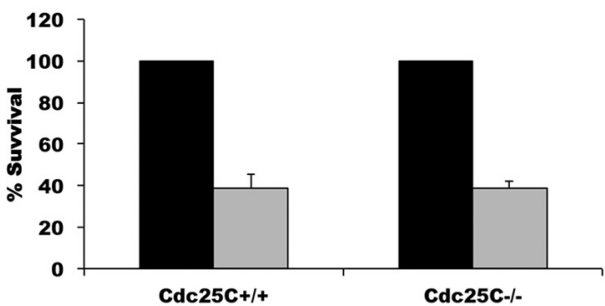

G

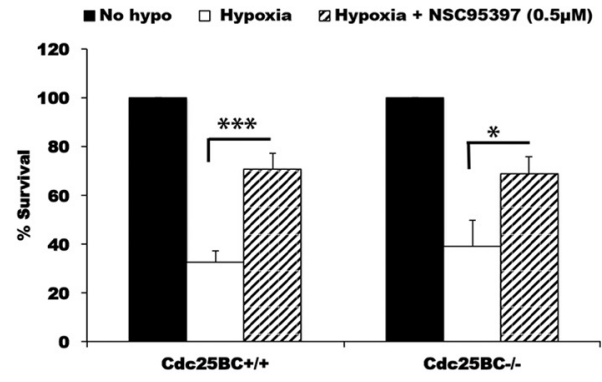

I

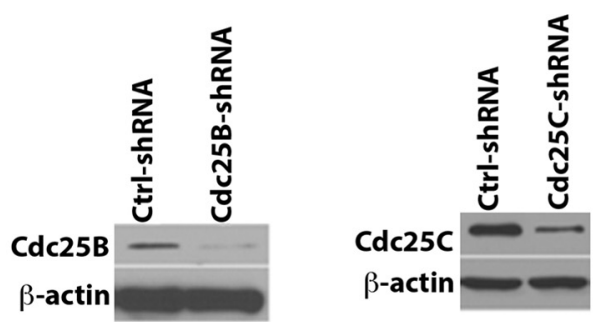

Figure 3. Cdc25A knockdown protects neurons from delayed cell death induced by hypoxia. $A, B$, CGNs were infected with AAV expressing shRNA to Cdc25A or control shRNA and subjected to $18 \mathrm{~h}$ of hypoxia in the presence of MK801. $A$, Confocal microscopy images of virally infected CGNs expressing shRNA and GFP $24 \mathrm{~h}$ after hypoxia. Neurons were counterstained with Hoechst stain (blue). Scale bar, $30 \mu \mathrm{m}$. B, Quantitation of neuronal survival $24 \mathrm{~h}$ after hypoxia in cells infected with AAV expressing Cdc25A shRNA or control shRNA. Survival was assessed by scoring live GFP ${ }^{+}$neurons over total infected cells. $N=3 .{ }^{* *} p<0.01$, statistical significance by two-tailed Student's test. C, Western blot analysis showing Cdc25A knockdown in cultured GGNs infected with AAV expressing shRNA to Cdc25A. D-F, CGNs from transgenic mice null for Cdc25B $(+/+, N=5 ;-/-, N=4 ; \boldsymbol{D})$ and Cdc25C $(+/+, N=4 ;-/-, N=3 ; \boldsymbol{E})$ or doubly null for Cdc25B and Cdc25C $(+/+, N=$ $5 ;-/-, N=3 ; \boldsymbol{F})$ were subjected to hypoxia plus MK801 as in $A$ and were assessed for survival $24 \mathrm{~h}$ later. Cell viability was assessed by the integrity of nuclei. Deficiency in Cdc25B or Cdc25C or their combined deficiency had no effect on neuronal survival. G, Rescue of neuronal survival in Cdc25B and Cdc25C double-knock-out neurons by NSC95397. Cdc25BC wild-type ( $N=5$ ) or double-deficient $(N=3)$ neurons were treated with or without $0.5 \mu \mathrm{M}$ NSC95397 and subjected to hypoxia plus MK801, as in $A$. Cell survival was assessed $24 \mathrm{~h}$ later. Results are expressed as the percentage of control $\pm \mathrm{SEM}$. ${ }^{*}$ Denotes statistical significance at $p<0.05 ;{ }^{* * *} p<0.005$, two-way ANOVA, followed by Tukey's multiple-comparison test. (Figure legend continues.) 
Membranes were probed with the following antibodies: anti-Cdc25A (catalog \#ab47400, Abcam, RRID:AB_869076; catalog \#sc-97, Santa Cruz Biotechnology, RRID:AB_2075041); anti-Cdc25B (catalog \#9525S, Cell Signaling Technology; RRID:AB_10694926); anti-pRb Ser795 (catalog \#9301S, Cell Signaling Technology; RRID:AB_330013); anti-Cdc25C (cata$\log$ \#251725, Abbiotec, RRID:AB_10639350; catalog \#sc-327, Santa Cruz Biotechnology, RRID:AB_2075277); anti-pRb (catalog \#554136, BD Biosciences; RRID:AB_395259); anti-E2F1 (catalog \#ab135251, Abcam; RRID:AB_2631246); anti-Lamin B1 (catalog \#ab16048, Abcam; RRID: AB_10107828); and anti $\beta$-actin (catalog \#A5316, Sigma-Aldrich; RRID:AB_476743).

Statistical analysis. Multiple comparisons were analyzed using ANOVA, with post hoc test. Where appropriate, the Student's $t$ test was used for two-group comparisons.

\section{Results \\ Induction of Cdc25A phosphatase activity following hypoxic stress in vitro}

The Cdc25 dual specificity family of phosphatases is composed of three family members (Cdc25A, Cdc25B, and Cdc25C) that share a similar function in regulating the cell cycle (Ray et al., 2007a). Key cell cycle regulators acting downstream of Cdc25 are implicated in ischemic neuronal damage. However, direct evidence for Cdc25 involvement in stroke-related injury is lacking. Accordingly, we first determined whether there were perturbations in the levels of Cdc25 proteins following ischemia-related stresses in vitro. To this end, we subjected CGN cultures to hypoxia in the presence of the NMDA blocker MK801, as previously described (Rashidian et al., 2005). In this model, neuronal death occurs in a delayed manner and is reliant on Cdk4 (Rashidian et al., 2005). As shown in Figure $1 A-F$, the levels of Cdc25A (Fig. $1 A, D$ ), Cdc25B (Fig. $1 B, E$ ), and Cdc25C (Fig. $1 C, F$ ) remained unchanged following up to $8 \mathrm{~h}$ of hypoxia in the presence of MK801. Although the levels of the Cdc25 proteins did not change following hypoxia, it is possible that there may be perturbations in their activity. Accordingly, phosphatase assays were conducted for each of the Cdc25 family members. As shown in Figure $1 G$, the activity of Cdc25A increased significantly at 2 and 8 h of hypoxia $(p<0.05)$ treatment. However, no significant changes were observed in the activity of Cdc25B (Fig. 1H) or Cdc25C (Fig. 1I) with hypoxia. A large variability was observed with the $\mathrm{Cdc} 25 \mathrm{~B}$ and $\mathrm{C}$ activity assays. Nevertheless, these results point to a potential role of $\mathrm{Cdc} 25 \mathrm{~A}$ in delayed ischemic neuronal death.

\section{Inhibition of Cdc25 protects neurons from delayed death mediated by hypoxia}

We next asked whether Cdc25 was required for delayed ischemic neuronal death. To this end, we used a pharmacological inhibitor of Cdc25. NSC95397 is a drug known to inhibit all three Cdc25 members (Lazo et al., 2002). However, it has been shown to exhibit some cytotoxic properties in dividing cell lines (Han et al., 2004). Accordingly, we first evaluated its cytotoxicity in our primary neuronal cultures. CGNs were treated with varying concentrations of NSC95397 up to $1.5 \mu \mathrm{M}$ and examined for neuronal survival $24 \mathrm{~h}$ later. As shown in Figure 2, $A$ and $B$, no cytotoxicity is observed when cultures are treated with up to $0.5 \mu \mathrm{M}$ NSC95397.

$\leftarrow$

(Figure legend continued.) $\boldsymbol{H}$, Rat CGNs were infected with AAV expressing control shRNA, Cdc25B shRNA, or Cdc25 C shRNA and subjected to hypoxia. Neuronal survival was assessed $24 \mathrm{~h}$ later as in $\boldsymbol{B}$. Data represent experiments performed in triplicate expressed as a percentage of survival \pm SEM. I , Western blot showing Cdc25B and CdC25C knockdown. Hippocampal lysate from rats expressing Cdc25B, Cdc25C, or control shRNA was subjected to Western blot analysis and probed with anti-Cdc25B or anti-Cdc25C antibodies. Actin was used as a loading control.
However, significant cell death is observed when neurons are treated with $1 \mu \mathrm{M}(\sim 68 \%$ survival $)$ and $1.5 \mu \mathrm{M}(\sim 2 \%$ survival $)$ NSC95397 $(p<0.01$ and 0.005 , respectively; Fig. $2 A, B)$. We therefore chose to test the Cdc25 inhibitor at concentrations between 0.1 and $0.5 \mu \mathrm{M}$.

To test whether Cdc25 is required for delayed neuronal death, we treated CGN cultures with up to $0.5 \mu \mathrm{M}$ NSC95397 before insult and subjected them to hypoxia for $18 \mathrm{~h}$ in the presence of MK801, as previously described (Rashidian et al., 2005). In the absence of insult, MK801 has no effect on neuronal survival (Fig. $2 C)$. The addition of MK801 in this model prevents excitotoxic cell death during hypoxia. Consequently, neuronal death occurs in a delayed manner during reoxygenation, with the majority of cell death occurring $24 \mathrm{~h}$ following hypoxia. Neuronal survival in the NSC95397-treated cultures was examined at 1, 2, and $4 \mathrm{~d}$ following hypoxia. As shown in Figure 2, $D$ and $E$, CGN cultures treated with the Cdc25 inhibitor were significantly more resistant to hypoxia-induced delayed neuronal death (Fig. 2D,E). Treatment with the Cdc25 inhibitor provided significant protection against delayed neuronal death at all concentrations tested $24 \mathrm{~h}$ following hypoxia (Fig. 2E). Remarkably, neurons treated with the Cdc25 inhibitor remained significantly protected from delayed death $4 \mathrm{~d}$ after insult. Neuronal survival was reduced to $15 \%$ in the no-drug-treatment control cultures $4 \mathrm{~d}$ after hypoxia. In contrast, neuronal survival was $46 \%$ at $0.1 \mu \mathrm{M}$ concentration $(p<0.01), 75 \%$ at $0.2 \mu \mathrm{M}$ concentration $(p<0.0001), 79 \%$ at 0.3 $\mu \mathrm{M}$ concentration $(p<0.0001), 88 \%$ at $0.4 \mu \mathrm{M}$ concentration $(p<0.0001)$, and $90 \%$ at $0.5 \mu \mathrm{M}$ concentration $(p<0.0001)$ in the Cdc25 inhibitor-treated cultures (Fig. 2E).

\section{Cdc25A, but not Cdc25B or Cdc25C, is required for delayed death by hypoxia}

The above results demonstrate the importance of Cdc25 in delayed neuronal death. However, it is unclear whether all three member or a single member of the Cdc25 family is required for death. We therefore sought to determine whether a deficiency in Cdc25A, Cdc25B, or Cdc25C is able to protect neurons from delayed death induced by hypoxia. Mice singly or doubly null for Cdc25B or Cdc25C are viable; however, mice null for Cdc25A die very early in development (Ray et al., 2007b; Lee et al., 2009). To circumvent the lethality of Cdc25A, we generated rAAV, expressing shRNA to Cdc25A. The rAAV also expressed GFP from a separate promoter. CGN cultures were infected $1 \mathrm{~d}$ after plating with AAV-expressing Cdc25A shRNA or control shRNA. Infection was monitored by GFP expression (Fig. 3A). Neuronal cultures infected with Cdc25A shRNA as well as CGNs singly or doubly null for Cdc25B and Cdc25C were subjected to $18 \mathrm{~h}$ of hypoxia in the presence of MK801, as described above. Survival was examined $24 \mathrm{~h}$ later in the virally infected cells by scoring the number of live GFPs over total GFP-positive cells and was expressed as the percentage of survival. Cell viability was assessed in the null cultures by counting the number of healthy nuclei after lysis with a mildly disruptive buffer. As shown in Figure 3B, neurons expressing Cdc25A shRNA were significantly more resistant to delayed death compared with those treated with control shRNA. Neuronal survival was $87 \%$ in the Cdc25A knock-down cultures compared with $64 \%$ in the control shRNA-expressing cells $(p<0.01$; Fig. 3B). Cdc25A knockdown in infected cultures was verified by Western blot (Fig. $3 C$ ). In contrast to Cdc25A, the loss of Cdc25B (Fig. 3D), Cdc25C (Fig. 3E) or their combined deficiency (Fig. $3 F$ ) did not provide neuronal protection following hypoxia. There was no difference in survival between wildtype neurons and those deficient for Cdc25B (Fig. 3D), Cdc25C (Fig. 3E), or Cdc25B/Cdc25C combined (Fig. 3F). However, 
A

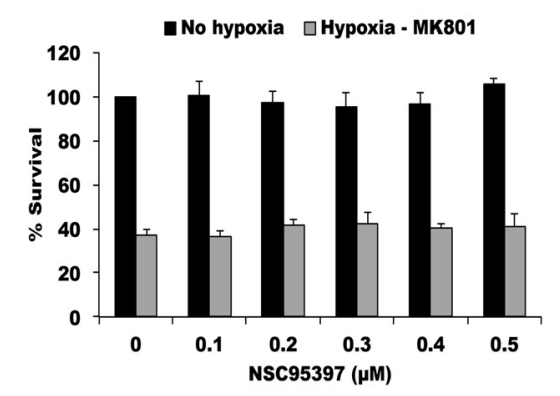

D

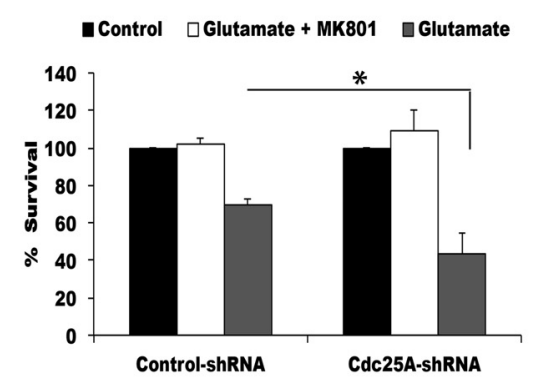

G

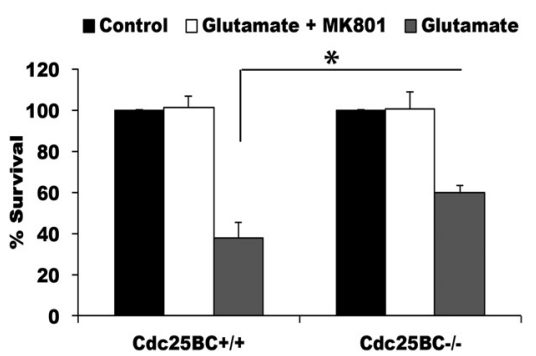

J

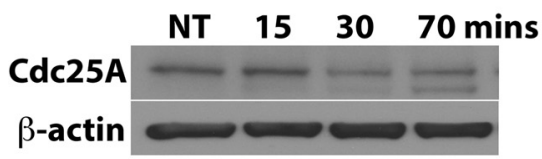

B

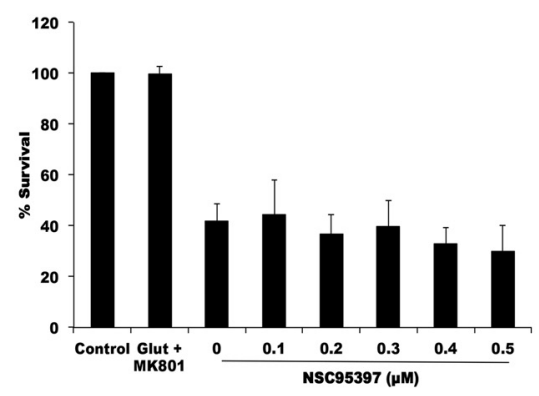

E

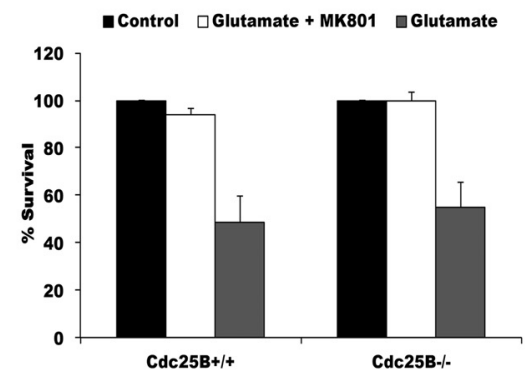

H

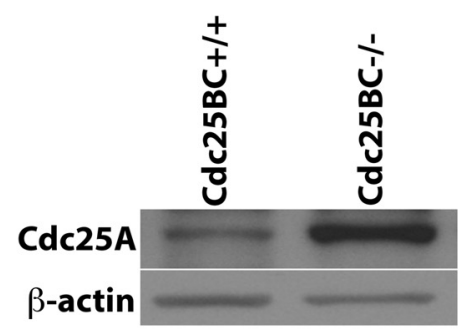

C

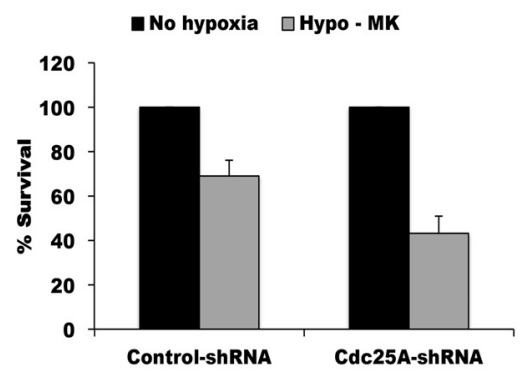

$\mathbf{F}$

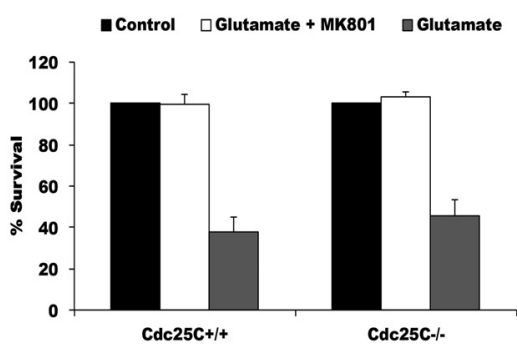

I

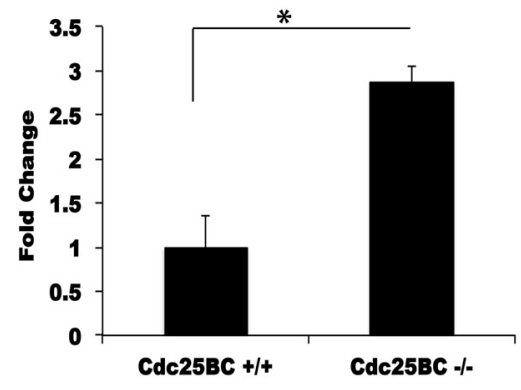

$\mathbf{L}$

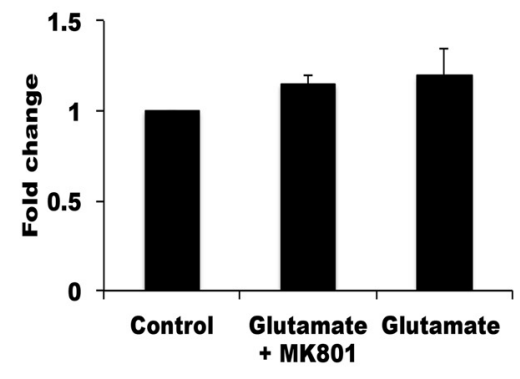

Figure 4. Cdc25A knockdown sensitizes (GNs to excitotoxic death mediated by hypoxia and glutamate. CGN cultures were treated with varying concentrations of Cdc25 inhibitor NSC95397 and were subjected to $5 \mathrm{~h}$ of hypoxia in the absence of MK801. Neuronal survival was assessed following $1 \mathrm{~h}$ of reoxygenation. $N=3 . A, B$, CGNs treated with NSC95397 were subjected to $50 \mu \mathrm{m}$ transient glutamate exposure for $70 \mathrm{~min}(\boldsymbol{A})$ and then and examined for survival $1 \mathrm{~h}$ later $(\boldsymbol{B}) . N=3$. C, D, CGNs infected with AAV expressing shRNA to Cdc25A or control shRNA were treated with hypoxia without MK801 and assessed for survival. $N=3, p=0.068$ (Student's $t$ test, two-tailed test; $\boldsymbol{C}$ ) or transient glutamate exposure, $N=3 .{ }^{*} p<0.05$ (Student's $t$ test, two-tailed test; $\boldsymbol{D}$ ). Neuronal

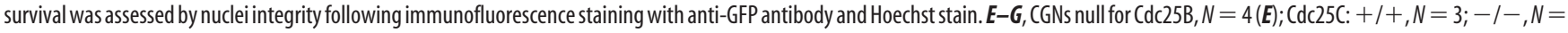
$5 ; \boldsymbol{F}$ ) or doubly null for $\left(\mathrm{dc} 25 \mathrm{~B}\right.$ and $\mathrm{Cdc} 25 \mathrm{C},+/+, \mathrm{N}=5$ and $-/-, \mathrm{N}=5,{ }^{*} p<0.5$ (Student's $t$ test, two tail; $\boldsymbol{G}$ ) were subjected to transient glutamate treatment for 70 min and assessed for survival $1 \mathrm{~h}$ later. Neurons doubly null for Cdc25B and Cdc25 C showed resistance to glutamate-mediated excitotoxic death. $\boldsymbol{H}$, Western blot analysis showing increased Cdc25 A protein level in Cdc25B and Cdc25 (double-knock-out brain samples. I, Densitometry of Cdc25A protein as shown in $\boldsymbol{H}, \mathrm{N}=3,{ }^{*} p<0.5$ (Student's ttest, two tail).J, Western blot analysis of Cdc25 A protein levels following glutamate treatment for the indicated times. $\boldsymbol{K}$, Quantitation of $(d \mathrm{~d} 25 \mathrm{~A}$ protein levels as in $\boldsymbol{E} . N=3, p=0.053$ (Student's $t$ test, one-tailed test). $\boldsymbol{L}$, Cdc25A phosphatase activity following glutamate treatment for $30 \min . N=3$.

neuronal survival was rescued in the Cdc25B and Cdc25C double-null neurons with treatment with the $0.5 \mu \mathrm{M}$ Cdc25 inhibitor NSC95397 (Fig. 3G). The neuronal survival rate was 39\% compared with $69 \%(p<0.05)$ in the nontreated and
NSC95397-treated Cdc25BC ${ }^{-1-}$ neurons, respectively, $24 \mathrm{~h}$ following hypoxia. Neuronal survival was similarly rescued in the Cdc25BC ${ }^{+/+}$cells treated with $0.5 \mu \mathrm{M}$ NSC95397 $24 \mathrm{~h}$ after hypoxia (33\% vs $71 \%$, respectively, in the nontreated and drug- 
A
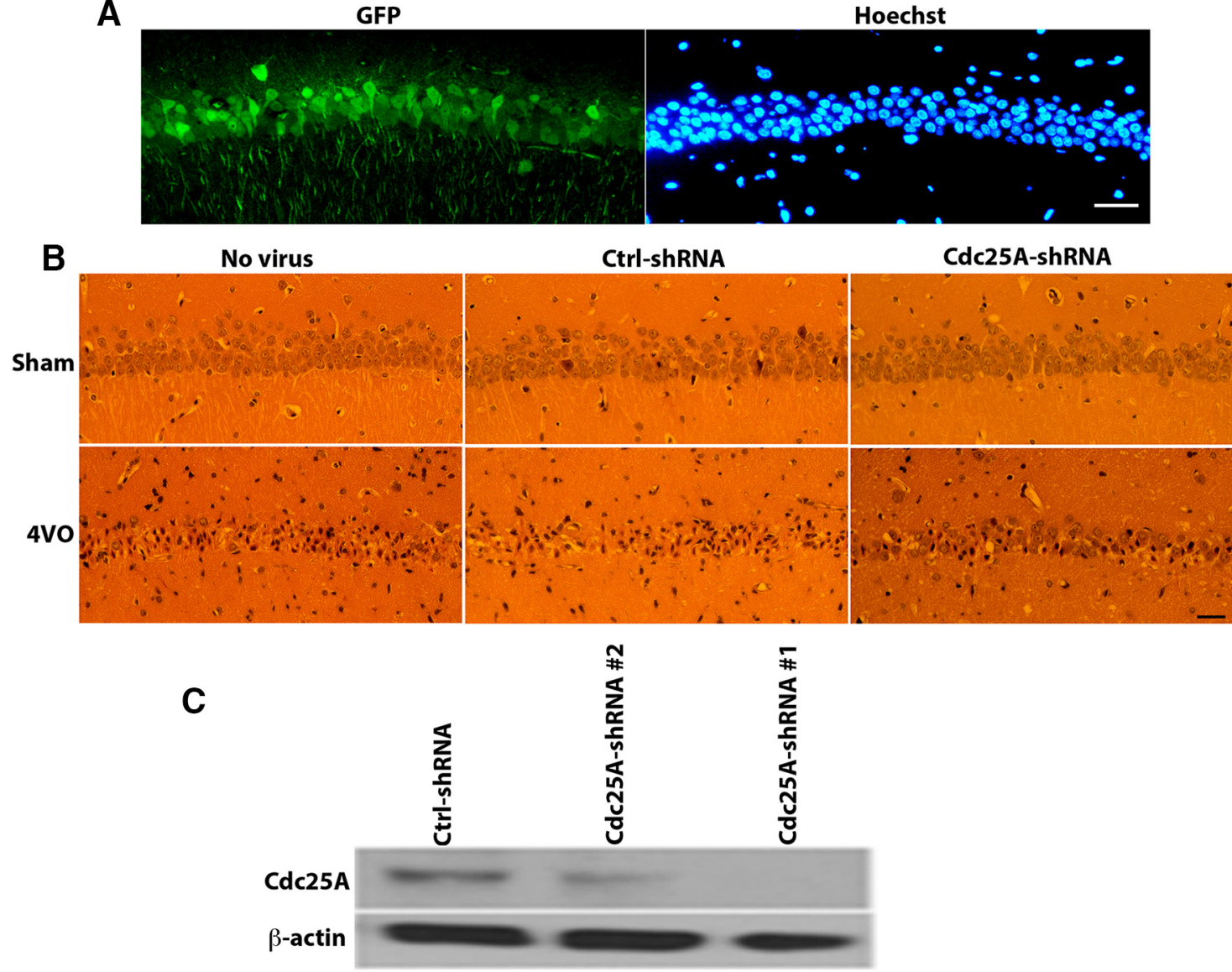

D

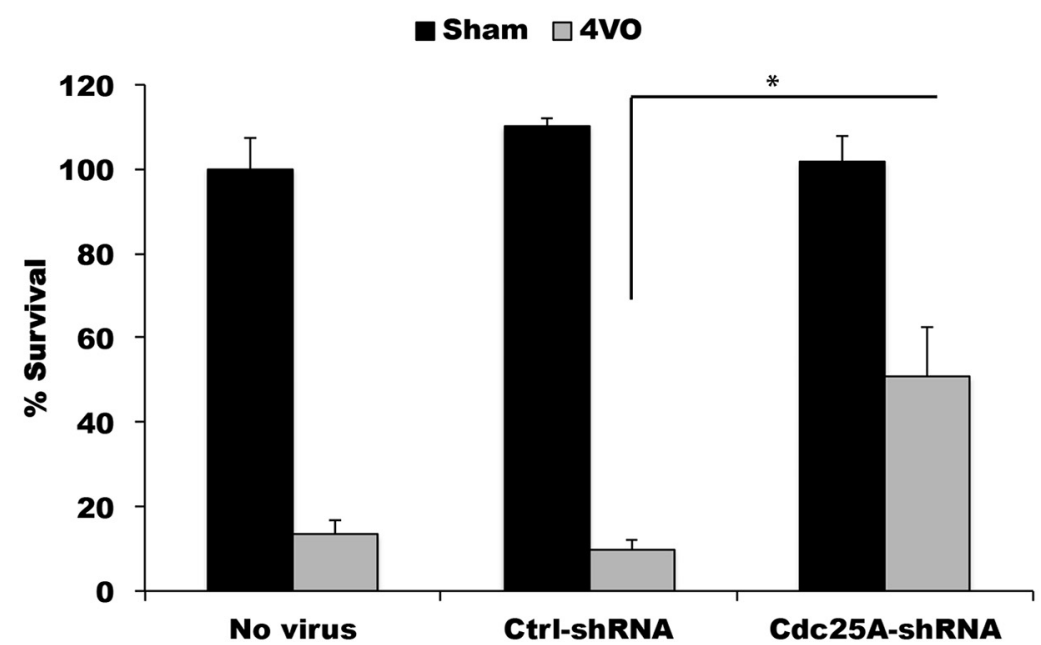

Figure 5. Cdc25A knockdown protects rat hippocampal CA1 neurons from delayed death mediated by global cerebral ischemia. $A$, Immunohistochemistry images showing GFP expression in hippocampal CA1 neurons in rats injected with AAV expressing shRNA. B, Representative hematoxylin and eosin-stained sections of hippocampal CA1 neurons of noninjected and AAV shRNAinjected sham and 4V0-treated rats. C, Western blot analysis showing Cdc25A knockdown in rats injected with AAV shRNA to Cdc25A. Two shRNAs were evaluated; shRNA 2 was chosen for in vivo studies. D, Quantitation of surviving CA1 neurons $4 \mathrm{~d}$ after $10 \mathrm{~min} 4 \mathrm{~V} 0$ in no-virus neurons $(N=3$ in sham and $4 \mathrm{~V} 0)$, $\operatorname{ctrl}$ shRNA $(N=4$ and 7 , sham and 4V0, respectively), and Cdc25A shRNA $(N=$ 5 and 8 , sham and 4V0, respectively) AAV-injected rats. Data are expressed as \pm SEM, ${ }^{*} p<0.05$, statistical significance compared with $4 V 0$ ctrl shRNA (ANOVA, followed by Tukey's multiplecomparison test).

treated cells; $p<0.005)$. To confirm our studies using Cdc25Band Cdc25C-null neurons, we also determined whether shRNAmediated knockdown of Cdc25B/Cdc25C would be protective against delayed death. To this end, rat CGNs were infected with AAV-expressing shRNA to Cdc25B, Cdc25C, or control shRNA and subjected to hypoxia. In this case, a rat system was used, since we already had validated shRNA targeting rat Cdc25B and
Cdc25C. As shown in Figure $3 H$, the neuronal survival rate in the Cdc25B knock-down cultures (64\%) was identical to that in controls $(61 \%) 24 \mathrm{~h}$ following hypoxia. Similar results were obtained with Cdc25C knockdown. Cdc25B and Cdc25C shRNAmediated knockdown was verified by Western blots (Fig. 3I). Together, these results suggest that downregulation of Cdc25A alone can provide resistance against delayed neuronal death. Im- 
portantly, it suggests a critical and distinct role for Cdc25A in delayed neuronal death with minimal contribution from Cdc25B and Cdc25C.

\section{Role of Cdc25A in excitotoxic neuronal death by hypoxia and glutamate}

Ischemia results in the activation of both delayed and excitotoxic death signals depending on the paradigm. The results above suggest that hypoxia-induced delayed death involves Cdc25A. However, it was unclear whether Cdc25A also plays a role in excitotoxic death. To this end, we examined the role of Cdc25A in neuronal death induced by excitotoxic insults. Neuronal cultures were subjected to $5 \mathrm{~h}$ of hypoxia in the absence of MK801 or a transient exposure to $50 \mu \mathrm{M}$ glutamate for $70 \mathrm{~min}$, as previously described (Rashidian et al., 2005). As shown in Figure 4, $A$ and $B$, pretreatment of CGN cultures with up to $0.5 \mu \mathrm{M}$ Cdc 25 inhibitor NSC95397 followed by exposure to either hypoxia (Fig. 4A) or glutamate (Fig. $4 B$ ) fails to protect neurons from death regardless of the drug concentration. The neuronal survival rate remained identical to control cultures even at the highest drug concentration tested $(0.5 \mu \mathrm{M} ; 34 \%$ vs $45 \%)$ following hypoxia (Fig. $4 A$ ) and following glutamate treatment ( $42 \%$ vs $30 \%$; Fig. $4 B$ ). This result suggests that, in contrast to delayed neuronal death, the Cdc25 signal is not required for excitotoxic cell death induced by hypoxia. However, NSC95397 inhibits all three Cdc25 family members. Thus, we wanted to confirm our results by specifically knocking down Cdc25A in our excitotoxic models. shRNAmediated downregulation of Cdc25A had no protective effect. It slightly sensitized neurons to both hypoxia-mediated ( $p=0.068$; Fig. $4 C$ ) and glutamate-mediated ( $p<0.05$; Fig. $4 D$ ) excitotoxic death when compared with control cultures. This is in contrast to our earlier observation with the Cdc25 inhibitor, where no sensitization occurred. This result prompted us to examine deficiencies in excitotoxicity in the other two Cdc 25 members. In contrast to Cdc25A, neurons deficient for Cdc25B or Cdc25C did not exhibit sensitization to glutamate exposure (Fig. 4E,F). Neuronal survival remained identical in Cdc25B-null neurons (49\% vs 53\%; Fig. 4E) and Cdc25C-null neurons (38\% vs 45\%; Fig. $4 F$ ) when compared with wild-type controls. Interestingly, the compound loss of Cdc25B and Cdc25C resulted in a slight but significant protection following glutamate exposure (39\% vs $60 \%$ in the $\mathrm{Cdc} 25 \mathrm{BC}^{+/+}$vs Cdc25BC ${ }^{-1-}$ neurons, respectively; $p<$ 0.05; Fig. $4 G$ ). Further examination by Western blot analysis showed that Cdc25A protein was overexpressed in the brain tissues of these mice (Fig. $4 H, I$ ). These results suggest that there is compensation in the Cdc25B and Cdc25C double-knock-out mice. We next wanted to determine whether there were perturbations in Cdc25A protein or activity following excitotoxic insult. Western blot analysis showed a decrease in Cdc25A protein level following glutamate exposure for $70 \mathrm{~min}$ (Fig. $4 \mathrm{~J}$, K). However, this reduction was not statistically significant. Examination of Cdc25A activity showed that it was unchanged by glutamate treatment for $30 \mathrm{~min}$ (Fig. $4 L$ ). Together, these results suggest that Cdc25A may have a subtle but significant role in excitotoxicity whereby its downregulation sensitizes rather than protects neurons from death.

\section{Cdc25A knockdown protects CA1 neurons from global ischemia}

The evidence above indicates a role for Cdc25A in delayed ischemic death in vitro. We next asked whether Cdc25A might play a physiological role in the adult model of global cerebral ischemia, which is predominantly associated with delayed death. The global
A

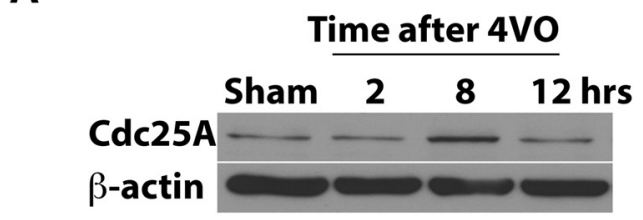

B

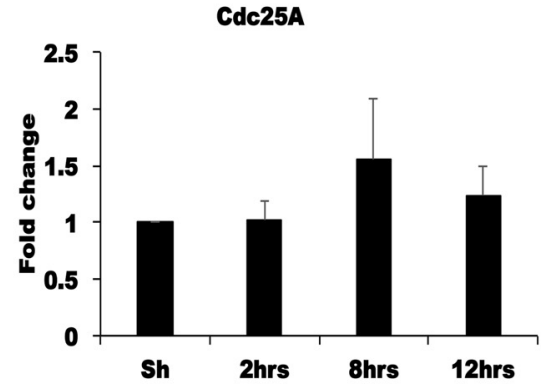

C

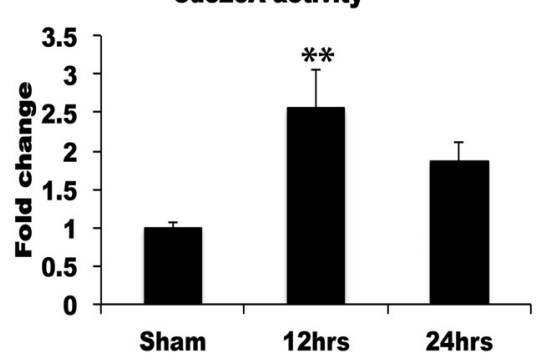

Figure 6. Cdc25A activity is induced in vivo following global cerebral ischemia. $\boldsymbol{A}$, Western blot analysis time course of $C \mathrm{dc} 25 \mathrm{~A}$ protein levels following global ischemia. $\boldsymbol{B}$, Densitometry of Cdc25A protein levels as in $\boldsymbol{A}$. $\boldsymbol{N}=4$. C, Phosphatase activity of $\mathrm{Cdc} 25 \mathrm{~A}$ is induced following global cerebral ischemia in rats. Rats were subjected to sham or $10 \mathrm{~min} 4 \mathrm{~V} 0$ followed by 12 or $24 \mathrm{~h}$ reperfusion. Cdc25A was immuonoprecipitated and subjected to phosphatase assay using pNPP as a substrate. Cdc25 activity was assayed by measuring the liberation of pNPP substrate at OD 410. Results are expressed as the fold change over sham control \pm SEM. ${ }^{* *} p<0.01$ (ANOVA, followed by Tukey's multiple-comparison test). $N \geq 6$.

cerebral ischemia model is not very reproducible in mice. We therefore switched to a rat system. Rats were injected unilaterally with AAV expressing shRNA to Cdc25A and GFP. As a control, a separate group of rats was injected with AAV expressing control shRNA. 4VO was induced 2 weeks following AAV injection, as previously described (Rashidian et al., 2005). Rats were killed $4 \mathrm{~d}$ following global ischemia. Viral delivery and infection were tracked by staining for GFP expression in the rat hippocampus (Fig. 5A). Two different shRNAs targeting Cdc25A were tested. Western blot analysis demonstrated efficient knockdown of Cdc25A with both shRNAs (Fig. 5C). shRNA 2 was chosen for further studies in vivo. As shown in Figure 5, $B$ and $D$, ctrl shRNA injection on its own or Cdc25A knockdown alone did not cause neuronal death in the absence of insult when compared with the no-virus control (Fig. 5B,D, black bars). However, upon ischemic insult, neuronal survival in the hippocampal CA1 decreased dramatically to $13 \%$ and $10 \%$, respectively, in the no-virus and ctrl shRNA groups (Fig. 5B,D, gray bars). However, neuronal survival was significantly improved in the Cdc25A knock-down group (Fig. $5 B, D$ ) compared with the control shRNA group (Fig. $5 B, D ; 10 \%$ vs $51 \%$, respectively, in the control and Cdc25A knock-down groups; $p<0.05$ ). These results are in agreement with our in vitro data, demonstrating a role for Cdc25A in delayed ischemic neuronal death. 
A

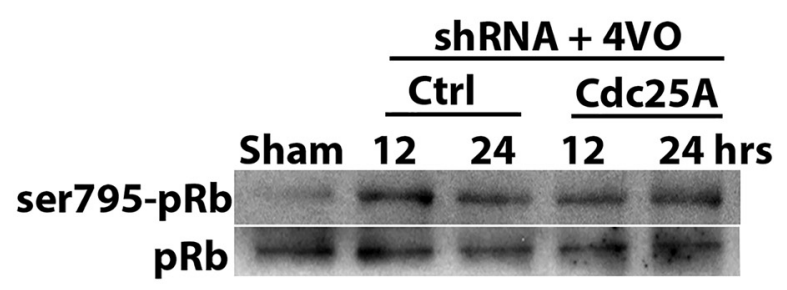

C

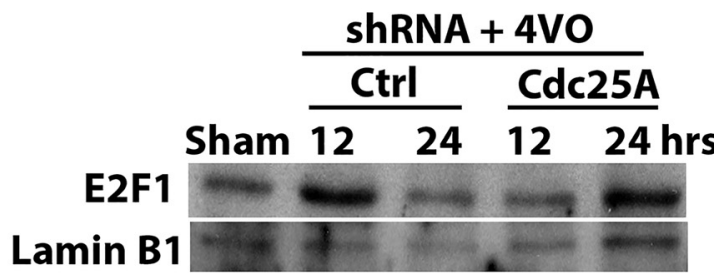

B

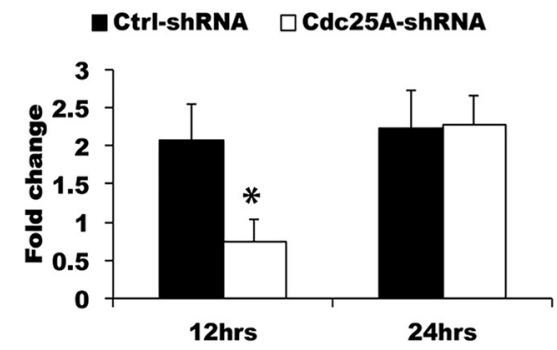

D

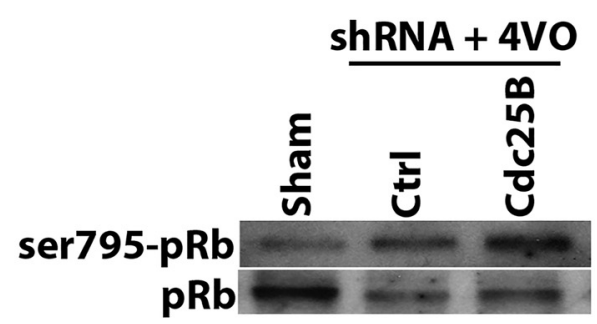

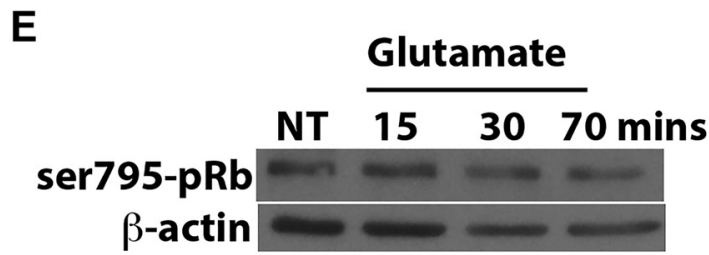

Figure 7. Induction of $\mathrm{pRb}$ phosphorylation following ischemic insult. $\boldsymbol{A}$, Western blot analysis was performed on nuclear lysate of hippocampal samples obtained from rats treated with Cdc25A or control shRNA. Rats were subjected to $10 \mathrm{~min}$ of $4 \mathrm{VO}$, followed by reperfusion for 12 or $24 \mathrm{~h}$. Blots were probed with anti-pRb Ser795 and anti-Rb antibodies. $\boldsymbol{B}$, Densitometry of Ser795 phosphorylated pRb, as shown in $\boldsymbol{A}$. Results are expressed as the fold change in $\mathrm{pRb} \pm \mathrm{SEM}$. ${ }^{*} p=0.038$ statistical significance by Mann-Whitney test, $N \geq 3$. $\boldsymbol{C}$, Hippocampal nuclear extracts from rats treated with Cdc25A or control shRNA followed by $4 \mathrm{~V} 0$ as in $\boldsymbol{A}$ were subjected to Western blot analysis and probed with anti-E2F1 or anti-Lamin B1 antibodies. $\boldsymbol{D}$, Western blot analysis was performed on hippocampal nuclear lysate obtained from rats treated with Cdc25B or control shRNA and subjected to 10 min of $4 \mathrm{VO}$ as in $A$ and probed with anti-pRb Ser795 and anti-Rb antibodies. $\boldsymbol{E}$, Western blot analysis of pRb phosphorylation in mouse CGN cultures exposed to glutamate. $N \geq 3$.

Cdc25A activity is induced in the rat global ischemia model As with our studies in vitro, we asked whether there were changes in the protein levels or activity of the Cdc25A. To this end, hippocampal tissue lysates from rats treated with $10 \mathrm{~min} 4 \mathrm{VO}$ and reperfusion for the indicated times were subjected to Western blot analysis and phosphatase assay. As shown in Figure 6, the protein levels of Cdc25A (Fig. 6A,B) were not significantly altered for up to $12 \mathrm{~h}$ following global ischemia. However, the activity of Cdc25A was significantly induced $12 \mathrm{~h}$ following global ischemia (Fig. 6C; $p<0.01$ ). This is in line with our earlier observation in vitro with delayed death following hypoxia. Importantly, Cdc25B (1.1- \pm 1-fold change over control) and Cdc25C activity did not change significantly $12 \mathrm{~h}$ following $4 \mathrm{VO}$. Together, these results demonstrate that in the context of delayed ischemic neuronal death, Cdc25A activity is increased and its downregulation is protective.

pRb phosphorylation is attenuated by Cdc25A knockdown The activity of Cdc25 is required for the activation of Cdk4 in proliferating cells. However, in neurons, Cdk4 has been shown to induce cell death by modulating the activity of the downstream $\mathrm{pRb} / \mathrm{E} 2 \mathrm{~F}$ pathway. We have previously shown, in the context of ischemia-induced delayed death, that $\mathrm{pRb}$ is increasingly phosphorylated at Ser795, a Cdk4-targeted site (Rashidian et al., 2005). Thus, we asked whether Cdc25A signals death via Cdk4 by examining $\mathrm{pRb}$ phosphorylation at Ser795. As shown in Figure 7, $A$ and $B$, phosphorylation of $\mathrm{pRb}$ at Ser795 is induced 12 and $24 \mathrm{~h}$ following 4VO. However, the expression of Cdc25A shRNA significantly attenuated $(p<0.05)$ pRb phosphorylation $12 \mathrm{~h}$, but not $24 \mathrm{~h}$, following ischemia (Fig. $7 A, B$ ). pRb is known to associate with members of the E2F family, preventing their activation. Accordingly, we queried the status of E2F1 in our 4VO model. Our analysis showed that the E2F1 protein level was increased $12 \mathrm{~h}$ following ischemia (Fig. 7C). Interestingly, shRNA-mediated knockdown of Cdc25A significantly delayed the timing of E2F1 induction similar to that of pRB (Fig. 7C). In contrast to Cdc25A, Cdc25B knockdown failed to attenuate $\mathrm{pRb}$ phosphorylation $12 \mathrm{~h}$ following $4 \mathrm{VO}$ (Fig. $7 D$ ). We also asked whether $\mathrm{pRb}$ signaling was perturbed following glutamate-induced excitotoxicity. As shown in Figure 7E, $\mathrm{pRb}$ phosphorylation was not induced following up to $70 \mathrm{~min}$ of glutamate exposure. This result suggests that there is little or no contribution of $\mathrm{pRb}$ signaling to neuronal death in this excitotoxic paradigm. Together, our results suggest a role for $\mathrm{Cdc} 25 \mathrm{~A}$ as a critical regulator of the $\mathrm{Cdk} 4 / \mathrm{pRb} / \mathrm{E} 2 \mathrm{~F}$ pathway in response to ischemic injury.

\section{Discussion}

The importance of Cdk4/pRb/E2F in ischemic neuronal death signaling has previously been demonstrated (Rashidian et al., 2005; Iyirhiaro et al., 2014). However, very little is known of the proximal signals that activate $\mathrm{Cdk} 4$ in the context of cerebral ischemic insult. In the present study, we have investigated the CDC25 family members as potential upstream regulators of the Cdk4-associated death signal in ischemia. We used both in vitro 
and in vivo models to examine whether the CDC25 family members are involved in ischemic neuronal death. Our data, using the pharmacologic inhibitor NSC95397, suggest that CDC25 family members are, in general, critical for delayed neuronal death. However, they are not essential for excitotoxic cell death in vitro. It is noteworthy that this inhibition paradigm prevented delayed neuronal death for up to $4 \mathrm{~d}$ following hypoxic insult without diminution in the level of protection over time.

A closer examination of whether all three or a single member of the Cdc25 phosphatase family is required for ischemic neuronal death supports a central role for Cdc25A. First, Cdc25A appears critical for delayed ischemic neuronal death in vitro and in vivo. Cdc25A knockdown is protective in delayed ischemic death induced by hypoxia in vitro and in vivo by global ischemia. Second, Cdc25A activity is significantly induced while those of Cdc25B and Cdc25C remain statistically unchanged. Cdc25A activity was increased by hypoxia in the presence of MK801 in vitro and following global ischemia in vivo. Interestingly, while Cdc25A promotes death in delayed ischemic models of death, its downregulation was slightly sensitized to death in response to excitotoxicity. The reason for this is unclear. Cdc25A has been shown to render HEK293 cells resistant to oxidant-induced cell death by physically interacting with apoptosis signal-regulating kinase 1 (ASK1), preventing its oligomerization and activation (Zou et al., 2001). However, it is unknown whether a similar mechanism exists in neurons. Interestingly, Cdc25A level, but not activity, was decreased following excitotoxicity. This is in contrast a to delayed model of ischemic death, where we observed a robust induction of $\mathrm{Cdc} 25 \mathrm{~A}$ activity. In addition, the loss of both $\mathrm{Cdc} 25 \mathrm{~B}$ and $\mathrm{Cdc} 25 \mathrm{C}$ resulted in slight protective effects from excitotoxicity associated with increased Cdc25A levels. It will be interesting to determine, in future studies, whether the physical interaction of Cdc25A (independent of its activity) with other death-related signals, such as ASK1/Cdc25A (Zou et al., 2001), is critical in regulating excitotoxic death.

How might Cdc25A promote delayed death? One way in which Cdc25A may mediate neuronal death is through Cdk4. In multiple neuronal death paradigms, the activation of Cdk4 is associated with an increase in Ser795 pRb phosphorylation (Park et al., 2000; Rashidian et al., 2005; Zhang et al., 2006). In line with this, we show in the present study that $\mathrm{pRb}$ phosphorylation at Ser795 phosphorylation is attenuated upon downregulation of Cdc25A in the global ischemia model. This suggests that Cdc25A may signal death following ischemia through Cdk4 activation. In agreement with this, expression of dominant-negative Cdk4 is protective against delayed death induced by ischemic insult and is associated with attenuation of Ser795 pRb phosphorylation (Rashidian et al., 2005). Induction of Cdk4 activity and pRb phosphorylation has been reported in other neuronal death models, including DNA damage (Park et al., 1998b, 2000; Zhang et al., 2006). Interestingly, we have shown that Cdc25A is also required for neuronal death induced by DNA damage (Zhang et al., 2006), suggesting that Cdc25A-mediated activation may be a common mechanism whereby cell cycle signals are activated in delayed neuronal death. It is important to note that Cdc25A downregulation, particularly in vivo, only partially blocked death and only delayed pRB and E2F1 induction. The reason for this is unclear. It may be that the shRNA downregulation to Cdc25A was incomplete or that other regulators of $\mathrm{Cdk} 4$ may also be important. It is interesting to note that, similar to Cdc25A activity, we did not observe perturbation in pRb Ser795 phosphorylation following excitotoxicity. This suggests a context-dependent role for Cdc25A in delayed but not excitotoxic cell death.
Together, our results show that Cdc25A plays an important role in delayed neuronal death induced by ischemia. Our data support a model whereby Cdc25A activity is induced and leads to Cdk4 pathway activation in neurons undergoing delayed death following cerebral ischemia. Consequently, pRb is phosphorylated and E2F is induced, leading to cell death. In other neuronal death paradigms, such as those induced by NGF deprivation (Biswas et al., 2005) and $\beta$-amyloid (Biswas et al., 2007), the activation of $\mathrm{Cdk} 4$ is associated with the induction of more downstream death effectors, such as Myb and Bim. However, the relevance of these factors in Cdk4 signaling, in the context of ischemic neuronal death, is presently unclear and is a subject for future studies.

\section{References}

Biswas SC, Liu DX, Greene LA (2005) Bim is a direct target of a neuronal E2F-dependent apoptotic pathway. J Neurosci 25:8349-8358. CrossRef Medline

Biswas SC, Shi Y, Vonsattel JP, Leung CL, Troy CM, Greene LA (2007) Bim is elevated in Alzheimer's disease neurons and is required for $\beta$-amyloidinduced neuronal apoptosis. J Neurosci 27:893-900. CrossRef Medline

Cai K, Di Q, Shi J, Zhang Y (2009) Dynamic changes of cell cycle elements in the ischemic brain after bone marrow stromal cells transplantation in rats. Neurosci Lett 467:15-19. CrossRef Medline

Dhavan R, Tsai LH (2001) A decade of CDK5. Nat Rev Mol Cell Biol 2:749_ 759. CrossRef Medline

Ferguson AM, White LS, Donovan PJ, Piwnica-Worms H (2005) Normal cell cycle and checkpoint responses in mice and cells lacking Cdc25B and Cdc25C protein phosphatases. Mol Cell Biol 25:2853-2860. CrossRef Medline

Gendron TF, Mealing GA, Paris J, Lou A, Edwards A, Hou ST, MacManus JP, Hakim AM, Morley P (2001) Attenuation of neurotoxicity in cortical cultures and hippocampal slices from E2F1 knockout mice. J Neurochem 78:316-324. CrossRef Medline

Giovanni A, Keramaris E, Morris EJ, Hou ST, O'Hare M, Dyson N, Robertson GS, Slack RS, Park DS (2000) E2F1 mediates death of B-amyloid-treated cortical neurons in a manner independent of $\mathrm{p} 53$ and dependent on Bax and caspase 3. J Biol Chem 275:11553-11560. CrossRef Medline

Gopinathan L, Ratnacaram CK, Kaldis P (2011) Established and novel Cdk/ cyclin complexes regulating the cell cycle and development. Results Probl Cell Differ 53:365-389. CrossRef Medline

Guégan C, Lévy V, David JP, Ajchenbaum-Cymbalista F, Sola B (1997) c-Jun and cyclin D1 proteins as mediators of neuronal death after a focal ischaemic insult. Neuroreport 8:1003-1007. CrossRef Medline

Han Y, Shen H, Carr BI, Wipf P, Lazo JS, Pan SS (2004) NAD(P)H:quinone oxidoreductase-1-dependent and -independent cytotoxicity of potent quinone Cdc25 phosphatase inhibitors. J Pharmacol Exp Ther 309:64-70. CrossRef Medline

Hernández-Ortega K, Quiroz-Baez R, Arias C (2011) Cell cycle reactivation in mature neurons: a link with brain plasticity, neuronal injury and neurodegenerative diseases? Neurosci Bull 27:185-196. CrossRef Medline

Herrup K (2012) The contributions of unscheduled neuronal cell cycle events to the death of neurons in Alzheimer's disease. Front Biosci (Elite Ed) 4:2101-2109. CrossRef Medline

Hwang IK, Yoo KY, Cho BM, Hwang HS, Kim SM, Oh SM, Choi SK, Hwang DY, Won MH, Moon SM (2006) The pattern of E2F1 and c-myb immunoreactivities in the CA1 region is different from those in the CA2/3 region of the gerbil hippocampus induced by transient ischemia. J Neurol Sci 247:192-201. CrossRef Medline

Iyirhiaro GO, Brust TB, Rashidian J, Galehdar Z, Osman A, Phillips M, Slack RS, Macvicar BA, Park DS (2008) Delayed combinatorial treatment with flavopiridol and minocycline provides longer term protection for neuronal soma but not dendrites following global ischemia. J Neurochem 105:703-713. CrossRef Medline

Iyirhiaro GO, Zhang Y, Estey C, O’Hare MJ, Safarpour F, Parsanejad M, Wang S, Abdel-Messih E, Callaghan SM, During MJ, Slack RS, Park DS (2014) Regulation of ischemic neuronal death by E2F4-p130 protein complexes. J Biol Chem 289:18202-18213. CrossRef Medline

Jordan-Sciutto KL, Dorsey R, Chalovich EM, Hammond RR, Achim CL (2003) Expression patterns of retinoblastoma protein in Parkinson disease. J Neuropathol Exp Neurol 62:68-74. CrossRef Medline

Katchanov J, Harms C, Gertz K, Hauck L, Waeber C, Hirt L, Priller J, von 
Harsdorf R, Bruck W, Hortnagl H, Dirnagl U, Bhide PG, Endres M (2001) Mild cerebral ischemia induces loss of cyclin-dependent kinase inhibitors and activation of cell cycle machinery before delayed neuronal cell death. J Neurosci 21:5045-5053. Medline

Lazo JS, Nemoto K, Pestell KE, Cooley K, Southwick EC, Mitchell DA, Furey W, Gussio R, Zaharevitz DW, Joo B, Wipf P (2002) Identification of a potent and selective pharmacophore for $\mathrm{Cdc} 25$ dual specificity phosphatase inhibitors. Mol Pharmacol 61:720-728. CrossRef Medline

Lee G, White LS, Hurov KE, Stappenbeck TS, Piwnica-Worms H (2009) Response of small intestinal epithelial cells to acute disruption of cell division through CDC25 deletion. Proc Natl Acad Sci U S A 106:47014706. CrossRef Medline

Liu T, Perry G, Chan HW, Verdile G, Martins RN, Smith MA, Atwood CS (2004) Amyloid- $\beta$-induced toxicity of primary neurons is dependent upon differentiation-associated increases in tau and cyclin-dependent kinase 5 expression. J Neurochem 88:554-563. CrossRef Medline

Love S (2003) Neuronal expression of cell cycle-related proteins after brain ischaemia in man. Neurosci Lett 353:29-32. CrossRef Medline

MacManus JP, Koch CJ, Jian M, Walker T, Zurakowski B (1999) Decreased brain infarct following focal ischemia in mice lacking the transcription factor E2F1. Neuroreport 10:2711-2714. CrossRef Medline

MacManus JP, Jian M, Preston E, Rasquinha I, Webster J, Zurakowski B (2003) Absence of the transcription factor E2F1 attenuates brain injury and improves behavior after focal ischemia in mice. J Cereb Blood Flow Metab 23:1020-1028. CrossRef Medline

Moh C, Kubiak JZ, Bajic VP, Zhu X, Smith MA, Lee HG (2011) Cell cycle deregulation in the neurons of Alzheimer's disease. Results Probl Cell Differ 53:565-576. CrossRef Medline

Nguyen MD, Julien JP (2003) Cyclin-dependent kinase 5 in amyotrophic lateral sclerosis. Neurosignals 12:215-220. CrossRef Medline

O'Hare MJ, Hou ST, Morris EJ, Cregan SP, Xu Q, Slack RS, Park DS (2000) Induction and modulation of cerebellar granule neuron death by E2F-1. J Biol Chem 275:25358-25364. CrossRef Medline

O'Hare MJ, Kushwaha N, Zhang Y, Aleyasin H, Callaghan SM, Slack RS, Albert PR, Vincent I, Park DS (2005) Differential roles of nuclear and cytoplasmic cyclin-dependent kinase 5 in apoptotic and excitotoxic neuronal death. J Neurosci 25:8954-8966. CrossRef Medline

Osuga H, Osuga S, Wang F, Fetni R, Hogan MJ, Slack RS, Hakim AM, Ikeda JE, Park DS (2000) Cyclin-dependent kinases as a therapeutic target for stroke. Proc Natl Acad Sci U S A 97:10254-10259. CrossRef Medline

Park DS, Levine B, Ferrari G, Greene LA (1997) Cyclin-dependent kinase inhibitors and dominant negative cyclin-dependent kinase 4 and 6 promote survival of NGF-deprived sympathetic neurons. J Neurosci 17: 8975-8983. Medline

Park DS, Morris EJ, Stefanis L, Troy CM, Shelanski ML, Geller HM, Greene LA (1998a) Multiple pathways of neuronal death induced by DNAdamaging agents, NGF deprivation, and oxidative stress. J Neurosci 18: 830-840. Medline

Park DS, Morris EJ, Padmanabhan J, Shelanski ML, Geller HM, Greene LA (1998b) Cyclin-dependent kinases participate in death of neurons evoked by DNA-damaging agents. J Cell Biol 143:457-467. CrossRef Medline

Park DS, Morris EJ, Bremner R, Keramaris E, Padmanabhan J, Rosenbaum M, Shelanski ML, Geller HM, Greene LA (2000) Involvement of retino- blastoma family members and E2F/DP complexes in the death of neurons evoked by DNA damage. J Neurosci 20:3104-3114. Medline

Pines J (1995) Cyclins and cyclin-dependent kinases: a biochemical view. Biochem J 308:697-711. CrossRef Medline

Rashidian J, Iyirhiaro G, Aleyasin H, Rios M, Vincent I, Callaghan S, Bland RJ, Slack RS, During MJ, Park DS (2005) Multiple cyclin-dependent kinases signals are critical mediators of ischemia/hypoxic neuronal death in vitro and in vivo. Proc Natl Acad Sci U S A 102:14080-14085. CrossRef Medline

Rashidian J, Iyirhiaro GO, Park DS (2007) Cell cycle machinery and stroke. Biochim Biophys Acta 1772:484-493. CrossRef Medline

Ray D, Terao Y, Fuhrken PG, Ma ZQ, DeMayo FJ, Christov K, Heerema NA, Franks R, Tsai SY, Papoutsakis ET, Kiyokawa H (2007a) Deregulated CDC25A expression promotes mammary tumorigenesis with genomic instability. Cancer Res 67:984-991. CrossRef Medline

Ray D, Terao Y, Nimbalkar D, Hirai H, Osmundson EC, Zou X, Franks R, Christov K, Kiyokawa H (2007b) Hemizygous disruption of Cdc25A inhibits cellular transformation and mammary tumorigenesis in mice. Cancer Res 67:6605-6611. CrossRef Medline

Small DL, Monette R, Fournier MC, Zurakowski B, Fiander H, Morley P (2001) Characterization of cyclin D1 expression in a rat global model of cerebral ischemia. Brain Res 900:26-37. CrossRef Medline

Smith PD, Crocker SJ, Jackson-Lewis V, Jordan-Sciutto KL, Hayley S, Mount MP, O’Hare MJ, Callaghan S, Slack RS, Przedborski S, Anisman H, Park DS (2003) Cyclin-dependent kinase 5 is a mediator of dopaminergic neuron loss in a mouse model of Parkinson's disease. Proc Natl Acad Sci U S A 100:13650-13655. CrossRef Medline

Timsit S, Rivera S, Ouaghi P, Guischard F, Tremblay E, Ben-Ari Y, Khrestchatisky M (1999) Increased cyclin D1 in vulnerable neurons in the hippocampus after ischaemia and epilepsy: a modulator of in vivo programmed cell death? Eur J Neurosci 11:263-278. CrossRef Medline

Wang F, Corbett D, Osuga H, Osuga S, Ikeda JE, Slack RS, Hogan MJ, Hakim AM, Park DS (2002) Inhibition of cyclin-dependent kinases improves CA1 neuronal survival and behavioral performance after global ischemia in the rat. J Cereb Blood Flow Metab 22:171-182. CrossRef Medline

Wen Y, Yang S, Liu R, Simpkins JW (2005) Cell-cycle regulators are involved in transient cerebral ischemia induced neuronal apoptosis in female rats. FEBS Lett 579:4591-4599. CrossRef Medline

Zambrano CA, Egaña JT, Núñez MT, Maccioni RB, González-Billault C (2004) Oxidative stress promotes tau dephosphorylation in neuronal cells: the roles of cdk5 and PP1. Free Radic Biol Med 36:1393-1402. CrossRef Medline

Zhang Y, Qu D, Morris EJ, O'Hare MJ, Callaghan SM, Slack RS, Geller HM, Park DS (2006) The Chk1/Cdc25A pathway as activators of the cell cycle in neuronal death induced by camptothecin. J Neurosci 26:8819-8828. CrossRef Medline

Zolotukhin S, Potter M, Zolotukhin I, Sakai Y, Loiler S, Fraites TJ Jr, Chiodo VA, Phillipsberg T, Muzyczka N, Hauswirth WW, Flotte TR, Byrne BJ, Snyder RO (2002) Production and purification of serotype 1, 2, and 5 recombinant adeno-associated viral vectors. Methods 28:158-167. CrossRef Medline

Zou X, Tsutsui T, Ray D, Blomquist JF, Ichijo H, Ucker DS, Kiyokawa H (2001) The cell cycle-regulatory CDC25A phosphatase inhibits apoptosis signal-regulating kinase 1. Mol Cell Biol 21:4818-4828. CrossRef Medline 